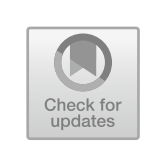

\title{
Cultural Constructions of Piracy During the Crisis Over Slavery
}

\subsection{Entanglements: Piracy and Slavery}

\subsubsection{From Exploration to Exploitation}

As early as 1700, Samuel Sewall, the renowned Boston judge and diarist, connected "the two most dominant moral questions of that moment: the rapid rise of the slave trade and the support of global piracy" in many American colonies (Hanna 2015, 292). In the course of the eighteenth century, three textual moments prepared the grounds for a major semantic shift in the trope of piracy in the Atlantic context, turning its primary connotations from exploration and adventure to slavery and exploitation. First, Daniel Defoe's popular 1720 pirate novel Captain Singleton depicted pirates who liberated slave-ships, implying that the real criminals were slave-traders rather than pirates while simultaneously emphasizing that pirates themselves often profited from the triangular trade. This picaresque novel follows its narrator-protagonist, who goes to sea at the age of twelve, makes a fortune, crosses Africa on foot, loses his money, and makes another gain as a pirate before he is ultimately reformed. Adventure story and travel narrative, it explores society from the point of view of its maritime outcasts with one exception: an African slave's perspective. The critique of slavery is a major issue in Singleton, yet is eventually contained by the economic system in which the pirates operate. The following episode is exemplary in the way the novel's discourse cannot but contain its critique. In it, Captain Singleton and his

(C) The Author(s) 2020

A. Ganser, Crisis and Legitimacy in Atlantic American Narratives of Piracy, Maritime Literature and Culture, https://doi.org/10.1007/978-3-030-43623-0_4 
ship encounter a "Multitude of black Sailors" that "terrify'd our Men" ([1720] 1969, 156); Bob's friend William the Quaker, the most radical outlaw figure of the book, to whose humanist and proto-enlightenment ideas much room is attributed, sets Singleton's racist prejudices straight:

I [Singleton] was struck with Horror at the Sight, for immediately I concluded, as was partly the Case, that these black Devils had got loose, had murthered all the white Men, and thrown them into the Sea; and I had no sooner told my Mind to the Men, but the Thought of it so enraged them, that I had much ado to keep my Men from cutting them all in Pieces. But William, with many Perswasions prevailed upon them, by telling of them, that it was nothing but what, if they were in the Negroes Condition, they would do, if they could; and that the Negroes had really the highest Injustice done them, to be sold for Slaves without their Consent; and that the Law of Nature dictated it to them; that they ought not to kill them, and that it would be wilful Murder to do it. ([1720] 1969, 156-57)

Convinced by William, the pirates take care of the slave ship and William cures some of the wounded Negroes and saves them from torture and rape. William embodies a didactic voice of reason in the book, and Singleton's development is greatly influenced by his teachings. Because of this narrative constellation, it is all the more telling that shortly after the slaves are well again, the pirates sell them to Caribbean planters: "having taken this Ship, our next Difficulty was, what to do with the Negroes" (16364). Singleton reflects on the situation of the market for slaves, knowing their inimical relations with the Portuguese prevents the selling of the Africans into Brazil, and, with the notable help of William, devises a plan to sell them to the Spaniards. The only motive given is that the pirates "should be no Way able to subsist them for so long a Voyage" (164). Due to their economic dependence on colonial mercantilism, we witness the shift of the narrative from abolitionist discourse to its complicity in the slave trade: there is no reflection on the sale itself, no self-criticism, no distance to or regret for the pirates' participation in human trafficking.

The second moment refers to the early drafts of the American Declaration of Independence (the version in John Adams' handwriting as well as Jefferson's), which labeled the British slave trade piratical. When Jefferson included a passage attacking slavery in his rough draft, it initiated the most intense debate among the delegates gathered at Philadelphia in early 1776. In what Jefferson called his "original rough draft" (Boyd 1999, 2), he embellishes an earlier version that reproached the crown 
for "prompting our negroes to rise in arms among us; those very negroes whom by an inhuman use of his negative he hath 'from time to time' refused us permission to exclude by law" (Jefferson 1776, n.p.) into a lengthy passage that he is the last in his list of grievances, so that the crescendo of indictments of the king shouts from the page. ${ }^{1}$ The British King, it read,

has waged cruel War against human Nature itself, violating its most sacred Rights of Life and Liberty in the Persons of a distant People who never offended him, captivating and carrying them into Slavery in another Hemisphere, or to incur miserable Death, in their Transportation thither. This piratical Warfare, the opprobrium of infidel Powers, is the Warfare of the Christian King of Great Britain. He has prostituted his Negative for Suppressing every legislative Attempt to prohibit or to restrain an execrable Commerce, determined to keep open a Market where Men should be bought and sold, and that this assemblage of Horrors might want no Fact of distinguished Die. (my emphasis)

As Malini Johar Schueller notes, Jefferson, in this passage, "dramatizes liberty all the more effectively in the context of piratical slavery, so that the empire for liberty is simultaneously the empire of virtue" $(1998,48)$. A few months earlier, John Adams, in a cautionary letter concerning American independence, had voiced his opinion in similar fashion, arguing that a series of British "Acts" had already dissolved the connections between America and Great Britain: the "prohibitory Act, or piratical Act, or plundering Act, or Act of Independency" (quoted in Armitage 2007, 34). Indeed, in August 1775, George III had declared the American colonists "rebels" no longer under the protection of the Crown (Armitage 2007, 33). Yet while Americans were rebels in the eyes of Great Britain, they were "not yet legitimate belligerents in the view of the rest of the world" (34): thus, the use of "piratical" by Jefferson highlights the goal of the Declaration of Independence: to delegitimize British sovereignty in America and establish legitimacy, appealing to the law of nations that defined piracy as beyond any legal norms and defeated the term "rebel" in its criminalizing implications by far. In the very moment of the political declaration of independence, in which the crisis of colonial legitimacy and representation would be performatively resolved-had the draft been accepted like this-, piracy was used to justify, in the claim that the British monarch was a pirate, that America acquired the natural right to break her bonds with this criminal. Armitage explains: 
However implausible it may have been to lay personal responsibility for the slave trade on the shoulders of George III, the comparison between "the CHRISTIAN king of Great Britain" and "infidel Powers" like those of Morocco and Algiers who engaged in "piratical warfare" against Europeans, outside the norms of the law of nations, recalled the charge in the Summary View that the king had "preferr[ed] the immediate advantages of a few British corsairs to the lasting interests of the American states, and to the rights of human nature, deeply wounded by this infamous practice, by refusing to countenance the abolition of the slave trade." (2007, 34)

Notably, this final charge was the only point in the list of grievances presented that was entirely deleted in the final version. It was replaced with a more ambiguous passage about King George's incitement of "domestic insurrections among us." Decades later, Jefferson blamed the removal of the passage on delegates from South Carolina and Georgia on the one hand and Northern delegates who represented merchants actively involved in the transatlantic slave trade on the other (58). Given the fact that Great Britain would abolish slavery roughly thirty years before the United States-and that Jefferson himself was a slave-owner-this is indeed an historical irony.

Commentators, most probably without even knowing Jefferson's draft formulation, in turn reversed the charge of piracy; Lind's Answer to the Declaration of Independence, for instance, refuted the U.S. claim to legitimacy in terms of their political agency, holding them to be nothing but rebels, themselves comparable to pirates: were the colonists acknowledged to be independent citizens of a foreign state, a pirate like Captain Kidd could likewise protect himself against prosecution by declaring himself independent. "Instead of the guilty pirate," Lind warned, "he would have become the independent prince; and taken among the 'maritime' powers-'that separate and equal station, to which'- he too might have discovered- 'the laws of nature and of nature's God entitled him" (quoted in Armitage 2007, 76). The label of piracy, in sum, floated in the air at the times of the revolutionary crisis and became the most radical signifier of illegitimacy for both Loyalists and Independents. The Declaration draft had linked it to slavery, yet that linkage never made it into the official version that became known to the world. 


\subsubsection{Barbary Pirate Narratives and U.S. Slavery}

Notably, Jefferson's distinctions between the United States and Britain in the Declaration of Independence draft draws on the cultural difference constructed between Christian and heathen, associating the British King with the "infidel powers" of North Africa and their corsairing economies (Schueller 1998, 48). The comparison between George III and the socalled Barbary corsair states of Morocco and Algiers hints at the third critical moment of literary associations of slavery and piracy: the genre of the Barbary captivity narrative, flourishing during the first foreign policy crisis with which the young Republic was confronted. The crisis became of national importance in 1794, when Algerian corsairs extended their actions to the Atlantic (Gilje 2004, 151), and culminated in the wars with "Barbary pirates" (1801-1805 and 1815), which also came to be the young nation's first armed conflict after independence from Great Britain. $^{2}$ When the colonies became independent, their eighty to one hundred Mediterranean trading ships were no longer protected by British tribute treaties with the Barbary states, resulting in a hundred Americans captured and enslaved by Algerian corsairs up to 1794 alone. ${ }^{3}$ Although by 1800 the United States had secured treaties with Morocco, Tripoli, and Tunis, the demand for ransom and tribute money increased steadily and eventually led to the First Barbary War (or Tripolitan War) in 1801, with a recently institutionalized American Navy eventually defeating the Ottoman powers of North Africa and reaching a fair treaty under Thomas Jefferson. Similar reasons were responsible for the Second Barbary War (or Algerine/Algerian War) in 1815, when the dey of Algiers took the War of 1812 as an occasion to renege on his treaty obligations (Leiner 2006). Again, the United States was successful, a victory that eventually led to the end of what was deemed North African corsairing and the Mediterranean tribute system. ${ }^{4}$

The Barbary crisis hence constituted the "founding period" in which "the blueprint for the American empire was drafted" (Mackenthun 2006, 4), with Jefferson's “crusader-like self-stylization" of the United States as an "empire for liberty" guiding this vision after the Louisiana Purchase (1803). When the American flag was raised on the walls of Derna, east of Tripoli, this moment of occupation was ritually reenacted on the U.S. stage to celebrate American liberty (5; Schueller 1998, 58). Texts dealing with the Barbary crisis "singled out the most despicable pirate behavior and compared it with the loftiest American ideals" (Lambert 2005, 106). 
"Barbarians" preferred piracy over legitimate trade, in this view, because they "simply operated outside the cultural norms of civilized society" (106). Algiers, Tunis, and Tripoli, supporting "pirates" and providing them with a safe haven, were seen as illegitimate, "piratical states" (Tyler [1797] 2002, 185), contrary to the British view that the corsairs were privateers backed by legitimate states (despite their semi-legal status, English print culture notably called them pirates rather than privateers; Hanna 2015, 204). American views condemned them as despotic "savages of the Seas" and as regimes inimical to democracy (Lewis 1990), calling Islam the main reason for the population's submissiveness (107) as it was deemed a religion of subjugation rather than (Christian) liberty (115). ${ }^{5}$

The North African perspective was of course quite different, insisting that this "piracy" needed to be judged in the larger historical context: "Americans and Europeans viewed the Spanish Reconquest as a legitimate reclamation of territory and sovereignty; the Moors ... pointed out that a longer view ... reveals that the real pirates and kidnappers were Europeans" (109) as Spain's expulsion of the Moors included the confiscation of Muslim property on the Iberian peninsula, a major reason for their corsairing out of economic motives (Baepler 2004, 106). What was conceived as a waterway toll the Americans were unwilling to pay was interpreted by them as illegitimate tribute according to a mare liberum and free trade logics. A view less prejudiced by Orientalist stereotypes (which are prevalent in many popular historiographies of the conflict until today) hence suggests that the corsairs functioned " $[\mathrm{m}] \mathrm{uch}$ less as a militant force in a Holy War than as entrepreneurs in a growing Mediterranean economy" (107). ${ }^{6}$

For Americans, however, piracy was also a cultural issue as pirates were cast as Barbarians, the term used in the Roman Empire for marauding Germanics and later attributed to North African Muslims, conjuring images of heathen outlaws that stood in stark contrast to enlightened republicanism (Baepler 2004, 110). At the same time, U.S.-American officials criticized European powers for paying these "pirates" for trade licenses; one diplomat describes "the dark cloud of shame which covers the great powers of Europe in their tame submission to the piracies of those unprincipled barbarians" (quoted in Tinniswood 2010, 280) until the young Republic itself had to enter negotiations with them. For some, like Consul General Richard O'Brien (who had been an Algerian prisoner for ten years himself), "the people that is stiled pirates in 
Barbary" were "no worse than British and French depredations" (quoted in Allison 1995, 155). A Philadelphia convention of a public pressure group, trying to persuade Congress to intervene in North Africa in 1794, even published a declaration that copied the rhetoric of grievances against Britain of the Declaration of Independence: "She has insidiously let loose the barbarians of Africa, to plunder and enslave the citizens of the United States. She has arrogantly attempted to prescribe boundaries to the American commerce: She has basely authorized piratical depredations to be committed ... on the ships and citizens of the United States" (quoted in Rojas 2003, 181-82). As most Americans also believed in British complicity with the corsairs,

[r]esisting the pirates meant asserting American sovereignty and America's right to nationhood. As the enslavement of European-Americans in Barbary became a crisis of international proportions, American writers recognized that their country's embarrassing position vis-à-vis Barbary undermined American rhetoric about the indolence enjoyed by the new nation. (Margulis and Poremski 2000, ix)

Outrage about paying tribute to "piratical" governments informed contemporary discussions of the problem as " $\mathrm{t}] \mathrm{o}$ pay tribute or buy peace seemed beneath the dignity of the new nation" (Rojas 2003, 170).

As Lambert notes, the U.S. view of the Barbary states changed over time: in the late eighteenth century, officials at least "shifted their perspective from regarding the pirates as fierce, fearless predators who had defied European powers for centuries, to regarding them as undisciplined, insolent, and vulnerable defenders of a bankrupt way of life" $(2005,111)$. At the same time, the use of the label "pirate" instead of corsair (the latter's legal status being similar to the privateer) increased during the crisis years, marking another change in American constructions of these men, "from men that had to be treated honorably to men that could be violently terminated" (Sutton 2009, n.p.) through military action (Jefferson at one point calls them "the piratical pestilence," quoted in Sutton 2009, n.p.). Evoking portrayals of Caribbean pirates, reports by captives were a cornerstone in this development as they cast the pirates as "childlike, capricious, and cruel" (Sutton 2009, n.p.) and the Barbary despots as weak, effeminate, and idle (Lambert 2005, 112), thereby displacing discourses about British (and European aristocratic) degeneracy onto Muslim Africans; these gendered tropes were taken up in Barbary captivity 
narratives. Rojas reports that the Barbary captivity tale was indeed "vital to the development of U.S. diplomatic practice and foreign policy" (2003, 159 ) as they redeemed "[f]eelings of humiliation, shame, impotence, and injured honor that pervaded the diplomatic correspondence well into the nineteenth century" (170) and legitimized military action. In his plea for naval intervention, Thomas Jefferson, for instance, also claimed that honor demanded such action (182) — countering John Adams' position that favored negotiation and a diplomatic solution.

Though another transatlantic, formally hybrid genre popular in England and Spain since their own conflicts with Barbary corsairs in the sixteenth and early seventeenth centuries, ${ }^{7}$ the captivity narrative fueled the development of a national U.S.-American literature in the Early Republic as it often articulated the experience of capture and enslavement by Muslim 'pirates' in terms of a dualistic (post-)Revolutionary rhetoric of freedom and slavery. By doing so it participated in the period's efforts at constructing an American national character through literary texts that took up these issues, thus negotiating the future character of the United States as slave-holding or free (Davidson 2004; Brezina 2005). Through these narratives, Americans tried to make sense of American identity by exploring differences between the U.S. and Barbary "pirates" (Sutton 2009 , n.p.). In addition, "[i]n dehumanizing the exotic and terrifying Other, the writers of the Barbary pirate slave narratives convinced the American public of the young nation's need to assert itself and triumph over a barbarous Republic's interactions with its own native populations." By harking back to the Indian captivity narrative and its tropes of Othering (especially those of savagery, paganism, and effeminacy), the genre's intertextual references Americanized it and distinguished it from its British counterparts. ${ }^{8}$ This Americanization, however, in fact continued a circular transatlantic literary exchange, with early modern European descriptions of pirate captivity in general and Barbary captivity in particular being taken up in early American Indian captivity narratives. The genre flourished in Europe at the same time that American colonization began, hence it is no surprise that European images of the Indian were reminiscent of those of infidel Moors. As Billy Stratton recently observed, ${ }^{9}$

the development of a system of transatlantic literary exchange ... resulted in a cartographical shift of the colonial gaze, from the dungeons and galleys of 
Constantinople, North Africa, and the Mediterranean to the dark, inhospitable forests of the northeastern woodlands. Given the prominence of the captivity theme in literary discourse of the sixteenth and seventeenth centuries, it should come as no surprise that the earliest descriptions of Native American people ... bear many similarities to descriptions of the Moors and Ottoman Turks found in preceding texts. $(2013,34-35)^{10}$

The delegitimizing rhetoric of Othering foreign agents by calling them pirates-in this case, an 'Oriental' Muslim Other associated primarily with the enslavement of Christians - was prominently articulated in this immensely popular genre. It mostly used an Orientalist discourse of monstrosity, inhumanity, and ungodliness in its construction of the Barbary pirate: "the American establishment perceived the Muslim as an enemy of the state, and its propagandists saw him as a subspecies whose idolatry rendered him incapable of any human compassion" (Montgomery 1994, 617). In the early Republic, the genre harked back to the seventeenth century, drawing on the Puritan image of the pirate as a licentious and devilish figure (Baepler 1995,111$)^{11}$ and on the earlier Barbary captivity narratives, British as well as American, set before the English-Algerian treaty of 1682 (115; e.g., the Narrative of Joshua Gee of Boston, Mass., While he was captive in Algeria of the Barbary pirates of 1680, the first American instance of the genre; see also Captain John Smith's report of Barbary capture, quoted in Baepler 1999, 7).

None of these texts could ignore that the United States itself was a slave power. Redirecting the interrelation of piracy and slavery from North Africa back across the Atlantic to North America, fictional and nonfictional narratives as well as plays and songs about North African captivity and enslavement-Susanna Rowson's Slaves in Algiers or, A Struggle for Freedom (1794) and Royall Tyler's The Algerine Captive (first published anonymously in 1797 and "plagiarized" from several popular Algerian captivity narratives, Davidson 2004, 300) the best known among them-effected the questioning of the legitimacy of slavery and unfreedom in terms of both race and gender in the United States, preparing the grounds for abolitionist discourses. ${ }^{12}$ In addition, Muslim slavery was often portrayed as much more humane, with conversion to Islam, for instance, resulting in instantaneous emancipation. Tyler's fictional narrative of Dr. Updike Underhill participated in the "then-current national preoccupation with the outrages perpetrated on Americans by Barbary pirates to expose worse outrages perpetrated by 
Americans on Africans" in a subversive plot that presents Algiers as a "distorted mirror version of America" ([1797] 2002, 300-301). Already in colonial times, Algiers, due to its image as piratical, had become an American moniker for absolutism, tyranny, roguery, white slavery, homosexual behavior, and cruelty (Hanna 2015, 205).

Rowson's play, primarily inspired by the debates around the Navy Act of 1794 over the strategy "to deal with the enslavement of the American seamen" and the decision "to reject the payment of ransom and to authorize the construction of ships in preparation for a possible war with Algeria" (Montgomery 1994, 618) articulated the struggle for liberty primarily in gendered terms but left the opposition between piratical North Africa and the United States 'Nation of Liberty' intact, pleading, however, that the United States do more to liberate its 'pirated' subjects, as Mr. Fennel's prologue exemplifies:

What then behoves it, they who help'd to gain,

A nation's freedom, feel the galling chain?

They, who a more than ten year's war withstood,

And stamp'd their country's honor with their blood?

Or, shall the noble Eagle see her brood,

Beneath the pirate kit's fell claw subdue'd? $([1794] 2000,7)^{13}$

As Robert Allison notes, the use of hyperbole in employing the word slavery itself can be viewed as more than just emphasizing abuse and the need for liberation; it highlights that the worst horror of slavery was the absence of liberty and freedom to move $(1995,112)$, but also effaces the difference between slavery in America and North Africa, where slaves "were not born into captivity or stolen from their homeland" (Baepler 1995,108 ) and could, by conversion or ransom, become free (Sutton 2009 , n.p.).

Two lesser known texts- the 1797 poem "The American in Algiers, or the Patriot of Seventy-Six in Captivity" and James Ellison's play The American Captive, or Siege of Tripoli (1811) - are worth mentioning in the context of my study. "The American in Algiers" tells both a story of a Bunker Hill veteran forced to go to sea out of economic necessity and enslaved by Algerian corsairs in the first canto, focusing the reader's attention to "that piratic coast where slavery reigns / And freedom's champions wear despotic chains" (quoted in Allison 1995, 90), and voiced a critique of America's continuation of slavery in the 
second: "[ $\mathrm{t}]$ he first canto chastises Americans for neglecting the men who had won their liberty [in their misery as Barbary captives]; the second condemns Americans for neglecting the very freedom these men had fought to secure" (91; the poem echoes Mathew Carey's comparison of Barbary with "all America south of Pennsylvania" as "hell," quoted in Allison 1995, 92). Ellison's "patriotic pageant" (Montgomery 1994, 623) about a power change in Algiers and the Algerine encounter with America as a yet undefined nation asks: "What constitutes legitimate power? and what is an American?" (Allison 1995, 201) by questioning the lawfulness of slavery and tyrannical regimes, comparing Algerian and Southern despotism more explicitly than for example Rowson's play. Both texts, along with New England newspapers denigrating Southern demagogues who preached equality while practicing "piratical barbarity" (quoted in Allison 1995, 99), anticipate the equation of Southern slavery and piracy on the Union envelopes of the Civil War (see Sect. 4.4).

All of these literary works exemplify how Muslim pirates, fictional or not, showed American Christians the sinfulness of slavery in a land of freedom (Allison 1995, 97):

Clearly, images of the Barbary pirates enslaving young American sailors affronts all that was hard won in the War for Independence. But when [they] ... draw an analogy between the barbarity of the foreign pirates and the cruelty of slaveholders at home, they suggest ... that the greatest enemy to America's institutions is not the enemy without but the more subtle enemy within. (Montgomery 1994, 630)

Hence also the interrelationship of the Barbary captivity narrative and the U.S. slave narrative that Paul Baepler explores in detail in his work with special reference to the only existing African American captivity narrative by a black American, The Narrative of Robert Adams, A Sailor, who was wrecked on the Western Coast of Africa of 1816 (1999, 20). Images of barbarity and civility in the former indeed came to question blackness and whiteness in the United States in the continued use of the Barbary narrative as a heterotopian mirror for self-exploration. Literary discourses as well as public intellectuals like Benjamin Franklin referenced the Barbary crisis to attack proslavery arguments in the United States. ${ }^{14}$ While Jefferson masked the parallel between North African and U.S. slavery, Franklin emphasized it in the last essay he published ("On the Slave Trade," 1836). Writing as Historicus, he ridicules Georgia 
congressman James Jackson's 1790 speech on slavery, which he read in the Federal Gazette by mock-praising it, saying it reminded him of a similar oration held by the dey of Algiers in 1687. Franklin turned Jackson's speech, which defended African slavery in America, into a defense of Christian slavery in North Africa (105; Leiner 2006, 19), drawing on climatic, economic, and class-related arguments such as that if Algiers gave up slavery and piracy, it would destroy its own economy just because people petitioned against slavery (Montgomery 1994, 615; Baepler 1999, $8)$.

Following Paul Baepler, ${ }^{15}$ however, it should be noted that tales of Anglo captivity in North Africa were used by both sides of the slavery debate to support their arguments, proslavery positions echoing a racial discourse that cast the African in general as barbarous and subhuman, thus justifying a regime of racial oppression. The use of the slippery signifier of piracy again supported what Baepler calls the "semiotic plasticity" that marks the genre $(1999,31)$. Also, slavery, not piracy, was at the center of Barbary captivity narratives and related texts on the crisis, as piracy functioned mainly as a framing device regarding both the texts' overall rhetoric and its place in the plot. While these literary works are set on the ocean only briefly, detailing the actual capture of American ships by Muslim 'pirates' (most of them were in fact European renegadoes), ${ }^{16}$ the signifier of piracy framed their debates about legitimacy, slavery, and freedom both abroad and at home, and the condemnation of North Africans as pirates was indeed "fundamental to all historical and cultural analyses" (Lambert 2005, 106). Piracy and trade, according to Frank Lambert, was a main dyad used by artists, journalists, historians, playwrights, poets, and other writers "in painting the Barbarians in dark and Americans in bright hues" (105):

To American audiences, the enemy was a band of lawless pirates who took what they wished from passing ships in ruthless attacks. Americans needed little prompting to understand these sinister characters because they knew about similar villains closer to home, ... fierce Caribbean buccaneers who showed no regard for human and property rights. By contrast, American saw themselves as champions of free trade ... No person or nation, from a pirate to the British Empire, had the right to interfere with the free exchange of goods. (105-106) 
The genre of the Barbary captivity narrative connected Revolutionary and Early American to Black Atlantic pirate narratives. The ship, though not the main setting of the Barbary tales, was associated in them with both physical and cultural mobilities as " $[\mathrm{t}]$ he rapid exchange of pirate tales and pirated imperial subjects [such as American tars impressed by the English or taken hostage by the corsairs] from ship to ship ... introduced provocative narratives of crime, ownership, and material value in a maritime system ... tyrannically managed and inflexibly hierarchical" (Blum 2003, 138). ${ }^{17}$ In the nineteenth-century context of the Black Atlantic, for which the Barbary captivity narrative laid the ground, ships became increasingly important as a heterotopian setting for the critique of slavery. The pirate ship, in that discourse, was conceived as a sovereign entity, opposing existing territorial states with a mobile space guided by laws different from those of the slave-holding United States. One of the most fascinating images of the pirate ship as heterotopia can be found in M.M. Philip's Black Atlantic novel Emmanuel Appadocca ([1854] 1997), which I analyze in the next chapter.

\subsection{Slavery and Piracy in the First Anglo-Caribbean Novel: M.M. Philip's EMMANUEL APPADOCCA ([1854] 1997)}

\subsubsection{The Ship and Black Atlantic Literature}

In the early modern Atlantic world, a large share of Atlantic seafaring took place in the service of the circum-Atlantic slave trade, serving European empire-building in the Americas. Because of their central position in the slave trade in particular, ships also became a popular literary topos for writers critiquing slavery. Ships have been cast as important sites of struggle and as symbols of escape in the context of a fledgling Black Atlantic consciousness, from Olaudah Equiano's Interesting Narrative (1789) and Richard Hildreth's The Slave: or Memoir of Archy Moore (1836; enlarged edition published as White Slave, 1852) to nineteenthcentury Atlantic abolitionist literature such as Frederick Douglass's $M y$ Bondage and My Freedom (1855) or Martin Delany's Blake (1859-1862). In these texts, the ship serves as a paradoxical symbol of both terror and freedom through which the foundational violence of the triangular trade is critiqued with regard to the enslavement and the forced relocation of Africans as well as to the unequal labor relations in the seafaring 
trades. Black and white abolitionists across the Atlantic world were imagining a different social order revolving around issues of resistance, liberty, (human) property, and (il)legality; hence it is not surprising that the nineteenth century would take up the motif of piracy in order to question the legitimacy of slavery in literary and other writings. In general, ships have been emblematic, ambivalent literary symbols for abolitionist and Black Atlantic literature due to the crucial transatlantic experience of the Middle Passage and their function as contact zones between different cultures, masters and slaves; the literary use of the pirate ship teases out these characteristics by creating a heterotopic, dialectical, and dynamic site of rebellion on the one hand and by emphasizing this site's tenuousness, fragility, and ultimate implication in that order on the other.

In the Black Atlantic context, the ocean, like the ship, similarly functions as an ambivalent, heterotopic site, "a trope marking the unruly space between the past memory of Africa and the present reality of slavery in terms of active resistance" (Pedersen 1994, 48). In literature, both the ship and the sea represent zones of cultural contact of a "motley crew" of subjects (also Klein and Mackenthun 2004; Birkle and Waller 2009); both are spaces characterized by fluidity and mobility, but they are also paradoxical spaces marked by both oppression and liberation. In The Black Atlantic: Modernity and Double Consciousness (1993), Paul Gilroy reads representations of ships and the sea in a double-edged manner as both a vehicle of exploitation and resistance. "[T] ime image of ships in motion across the spaces between Europe, America, Africa, and the Caribbean" (4) is evoked by Gilroy to highlight transnational movement within the sphere of the black diaspora. Ships, for Gilroy, not only recall the Middle Passage, but also subsequent travels of Afrodiasporic individuals and activists such as Delany or Douglass. Furthermore, the moving ship, as a symbol, represents "the moving to and fro between nations, crossing borders" and denote "micro-systems of linguistic and political hybridity" (12) due to their constant state of being in-between (nations, continents, cultures, etc.) at sea. Along with these forms of personal movement associated with the symbol of the ship, Gilroy foregrounds "the circulation of ideas ... as well as the movement of key cultural and political artefacts" as highly important means of Afrodiasporic cultural and political exchange within the black Atlantic world (4). James Procter summarizes that "[c]irculation, movement, passage and journeying are Gilroy's preferred metaphors here, allowing him to move beyond what he takes to be the narrow, sclerotic confines of the nation" (2007, 152). Gilroy 
indeed calls attention to the ideas of movement and mobility, which are key components of transnational cultural exchange, as opposed to stasis and the supposedly secure harbor of the nation-state. In his seminal study, he analyzes a number of literary works written by Afrodiasporic authors such as W. E. B. DuBois or Richard Wright. Yet, as Gesa Mackenthun (2004) has shown, the Black Atlantic paradigm can also provide new perspectives on maritime fiction by writers like James Fenimore Cooper or Herman Melville.

One subset of nineteenth-century maritime fiction of the Black Atlantic are narratives that fictionalize the pirate ship as a transnational and multiethnic contact zone. These texts exemplarily present the pirate ship as a space in which various discourses of legitimacy and illegitimacy meet. Piracy and slavery are discursively intertwined in order to question the dominant conceptions of law, might, and right. Such texts articulate the pirate ship as a site that allows for social critique, dialogue, and the destabilization of binary constructions of racial difference, one of the prime qualities Mary Louise Pratt attributes to cultural contact zones. Inspired by early modern accounts of piracy and popular short narratives about black pirates, Michel Maxwell Philip's 1854 Emmanuel Appadocca; or, Blighted Life: A Tale of the Boucaneers, sometimes claimed to be "the first Anglo-Caribbean novel" (Cudjoe 1997b, xiii-xiv), as well as Melville's "Benito Cereno" (1855/1856, see Sect. 3.3) characterize the pirate ship yet again as a mobile site of fluidity and uncertainty, of crisis and deception.

\subsubsection{The First Anglo-Caribbean Novel}

During the slavery crisis of the mid-nineteenth century, piracy signified the criticality of legitimacy in the context of Black Atlantic literature. Black Atlantic narratives responded to the crisis and voiced a critique of the triangular trade by turning the trope of the pirate as a figure of excessive consumption on its head. Using black pirates as figures of resistance to an exploitative system of enslavement and to the spectacle of colonial commodities, Maxwell Philip's novel Emmanuel Appadocca (1854) emphasizes the nexus of insatiable material desire and its conditions of production: slavery. In addition, Black Atlantic narratives of piracy also turn upside down the traditional definition of the pirate as renouncing all ties and laws of nature (e.g., by Hugo Grotius; see Greene 2008, 95): by appropriating claims to natural law as incompatible with a slave-based 
system, the pirate, paradoxically, becomes the outlaw defendant of laws of nature as opposed to legal law. By using the figure of the pirate in this way, the consumption of commodities produced by slave labor itself was delegitimized as these narratives evoked a conjuncture of piracy and slavery that had been introduced in the eighteenth century and was to be continued throughout the nineteenth, up to the Civil War.

Philip, a Trinidadian jurist of mixed descent, whom C. L. R. James hailed as "the most brilliant native of his time and within memory," "[p] erhaps the greatest of all creoles" ([1931] 1978, 255; 269), published Emmanuel Appadocca as a protest against slavery in the United States, lamenting the cruelty of "the slave holders of America" against "their slave-children" (Philip [1854] 1997, 6), by which the author particularly refers to the 'illegitimate' offspring of white masters and black enslaved mothers. ${ }^{18}$ The book presents "Philip and his character [as] ... vindicators who, like Frederick Douglass and C.L.R. James, would outread and outdignify the white oppressor" (Smith 1999, 171). Philip wrote and published the book while he was reading for the bar and working as a correspondent for a Trinidadian newspaper in London; the text, influenced by Sir Walter Scott's and James Fenimore Cooper's sea romances, is a transatlantic narrative that transcends national borders through its critique of race relations, connecting Great Britain, the United States, the Caribbean, and Africa on both the fictional and the metafictional levels. Part swashbuckling adventure, part philosophy, Emmanuel Appadocca mixes social critique and emancipatory claims on behalf of Philip's fellow creoles. In this chapter, I place Philip's understudied novel within the context of Paul Gilroy's concept of the Black Atlantic and, in a second step, critically discuss it as an instance of heterotopia, a space in which dominant conceptions of law and justice are questioned and refigured.

What makes Philip's novel such an important narrative intervention is the fact that it was the first to voice a subaltern subject position by placing at its center a creole protagonist of mixed descent who references the racial trope of the 'tragic mulatto,' while at the same time introducing a heroic non-white pirate and intellectual whose perspective is emphatically presented to the reader. In this way, the text negotiates the transatlantic phenomena of piracy and slavery through the perspective of a Black Atlantic consciousness by imagining the pirate ship as an imaginary site of resistance and dialogue. ${ }^{19}$ Emmanuel Appadocca is not the first book to bespeak a Black Atlantic consciousness in tackling slavery and its consequences through the trope of piracy, nor would it be 
the last. But, while Philip is not the first to critique slavery through the figure of the pirate, his novel may well be the earliest contribution by an African American to this literary tradition; its radical innovation was its sympathetic portrayal of a 'colored' pirate. In addition, "it was the first Anglo-Caribbean novel to [examine the subject of miscegenation] from the point of view of a colonized person" (Cudjoe 2003, 123).

Emmanuel Appadocca is autobiographically inspired; while Philip's parentage is not entirely clear, it is known that he was an illegitimate child, offspring of a white planter and a colored woman in Trinidad. In recognition of his intellectual capacities, he was sent to a Jesuit school in Scotland, where he received a classical education, learned many foreign languages, and entered a solicitor's office upon his return home (James [1931] 1978, 254-55). In 1851, he went to England to read for the bar; around this time, he wrote to his father asking for monetary help, a plea refused or at least neglected (255). Although Philip-a man famous for both intellectual wit and artistic temperament (263)-later became an esteemed member of Trinidadian society, a powerful orator, and an important legislator and commissioner, Appadocca proves, as C. L. R. James argued, "the powerful effect with which the misfortune of his birth weighed upon his mind" (255).

The text is a result of the Black Atlantic and its racial relations which fundamentally shaped Philip's biography: he crossed the ocean a number of times and actually wrote the novel in London as a response to the slavery crisis in the United States that followed the Fugitive Slave laws of $1850 .{ }^{20}$ The novel, "located within the literary, cultural, and socioeconomic context of the Atlantic world system" (Cain 1997, xv), is a "triangulated text" (xvi) that discusses slavery and piracy from a transnational, ex-centric perspective. Though it was apparently a popular book in its own times-Philip made enough money with it so as to finance months of traveling through Europe-the text had been largely forgotten until the 1997 publication of the University of Massachusetts Press edition (prepared by Selwyn Cudjoe). The generic affiliation with slave narratives is especially evident in the book's endorsement, written by Philip's supervisor and "Her Majesty's representative" (Philip [1854] 1997, 10) to counter contemporary racist claims against black authorship, which presents not only Philip's authorial skills but also his integrity as a Trinidadian citizen. In this context, William Cain states that the novel "is not only about a character of imposing strength of will, but also is ... intended as an act of will against the claims that persons of African descent are 
incapable of authorship" (1997, xlii). Told in the third person, it weaves together "the ideology of organized piracy" (Cudjoe 1997b, xiii) as parallel to the pirating of African slaves by whites and turns this ideology on its head when the colored creole hero becomes a pirate himself.

\subsubsection{Slavery, Piracy, Legitimacy}

In Emmanuel Appadocca, piracy is presented as a result of disenfranchisement on the one hand and as a source of empowerment and strength in the struggle against inequality and injustice-particularly against slavery and its consequences - on the other. In the novel, the pirate ship enacts a different sort of "imagined community" (Anderson [1983] 2006) than that of a nation-state, which excluded various groups of people due to its racist and classist colonial structures. Appadocca is Philip's only novel and articulates the injustice suffered by American children of mixed descent, whose white fathers abandon them, as well as by their mothers, using the topic of filial revenge, the trope of piracy, and the discourse of natural law. ${ }^{21}$ The novel can thus be read as a "meditation of how an enslaved person ought to behave under the crushing weight of slavery" (Cudjoe 1997b, xiii).

The plot concerns the desertion of the protagonist's mixedrace mother (she is most likely of black and Spanish descent) ${ }^{22}$ by his father, the wealthy British sugar planter James Willmington, and the son's attempt to restore his then deceased mother's honor. The story begins when Appadocca's pirate ship, significantly named The Black Schooner, captures Willmington's British merchant ship on which the creole pirate discovers his father. Following his plan of revenge, Appadocca punishes Willmington for leaving his mother and his illegitimate offspring by casting him out upon the sea, tied to a barrel. He unexpectedly survives and has Appadocca imprisoned on a British Navy's man-of-war, anchored close to the Danish colony of St. Thomas. Aboard ship, he encounters Charles, the son of the ship's admiral and an old friend and former fellow student in Paris. Appadocca tells Charles the story of how had to leave Paris after his mother's death: without money to sustain himself, he had to return to the Caribbean instead of finishing his education, where he then formed his pirate crew with the Caribbean buccaneers in order to take revenge on his father. Appadocca, showing his almost superhuman physical prowess, escapes from the Navy ship by swimming to the Venezuelan coast, where he rejoins the pirates and yet again takes his father prisoner. 
In a terrible hurricane, Willmington sinks with her, going "down into the Caribbean Sea like slaves on the middle passage trade he has profited from" (James 2002, 51), while the creole pirate-protagonist commits suicide by jumping off board, convinced that his mission is fulfilled. The trope of the tragic mulatto is rehearsed here as a "tragic tale of loss that Atlantic slavery endlessly repeated" (Cain 1997, 5), although Appadocca's death is narrated as a self-determined reunion with the ocean rather than as a suicide out of despair; hence, his end functions as a foil to Willmington's involuntary drowning: Appadocca bids farewell to his crew members Jack Jimmy and Lorenzo and "[w]ith a spring ... jumped from the rock and threw himself headlong into the thundering waves below" (Philip [1854] 1997, 244).

One of the central discourses in Emmanuel Appadocca is that of legitimacy, of rights and lawfulness, of both slavery and piracy, focusing on the natural right to resistance, which is here translated into violent, even selfdestructive vengeance. The most crucial scenes for the novel's inversive Black Atlantic commentary on slavery and piracy are the protagonist's conversations with his friend Charles. Notably, they take place on the Navy ship on which he is imprisoned: coming from the pirate schooner, a site of countercultural agency for Appadocca and his crew, he transfers its heterotopian and dialogic qualities onto this imperial vessel, trying to infuse it with a spirit of resistance that fundamentally questions the legal definition of piracy (which defines him as a criminal). About midway into the book, Appadocca gives a powerful speech in which he argues that colonialism itself is a piratical system:

If I am guilty of piracy, you, too-the whole of mankind is guilty of the very same sort of crime. ... [T] he whole of the civilized world turns, exists, and grows enormous on the licensed system of robbing and thieving, which you seem to criminate so much ... The people which a convenient position ... first consolidated, developed, and enriched, ... sends forth its numerous and powerful ships to scour the seas, to penetrate into hitherto unknown regions, where discovering new and rich countries, they, in the name of civilization, first open an intercourse with the peaceful and contented inhabitants, next contrive to provoke a quarrel, which always terminates in a war that leaves them the conquerors and possessors of the land. ... [T] he straggling and weakest portions of a certain race, whose power of bodily and mental endurance, renders them the likely objects to answer this end, are chosen. The coasts of the country on which nature 
has placed them, are immediately lined with ships of acquisitive voyagers, who kidnap and tear them away .... . (112-14)

In this astute analysis, slavery appears as a direct consequence of the colonial venture encompassing the entire "civilized world," and "powerful ships"- the narrator refers to the slavers here-are this world's empire builders. Appadocca's vessel of revenge, in contrast, is a highly mobile site of deviation and crisis, an embodiment of an inverted colonial order in which, in this case, the colored subject is the captain rather than the cargo, and formerly impressed sailors find relief in a community of almost-equals.

Yet Emmanuel Appadocca's pirate ship is by no means devoid of racial or class hierarchies. Her captain is a Byronic hero, a stoic scholarphilosopher and highly articulate "Quadroon," as contemporary racial terminology would have had it (Mackenthun 2004, 143). His light complexion is emphasized time and again to set him apart from the few blacks that are identified as such in the book, most notably the coon figure of Jack Jimmy, who is frequently compared to a monkey (Philip [1854] 1997, 38, 82) and whose physiognomy is repeatedly designed as the grounds for his typologically fixed role of a figure of comic relief (as he is abused by the crew for their amusement, for instance; 29-30).

The alleged violence of the Caribbean pirates-more specifically, the French "boucaniers" of the novel-is of special significance in the context of the text's discursive appropriation of piracy as a means of heterotopic resistance. ${ }^{23}$ As William Cain points out, Uncle Tom's Cabin of 1852, a book Philip doubtlessly knew when he crafted Appadocca, had made the diabolic Simon Legree an apprentice among these pirates (1997, xxxv), and Appadocca takes up and refashions this motif of piracy as a response to the Fugitive Slave Act. Moving from the Caribbean background toward the ocean in its setting, Philip's novel inverts the significance of this Atlantic motif through the association of piracy with a rough, quasidemocratic, revengeful Robin Hood principle (Cudjoe 2003, 125; Lewis [1983] 2004, 81), "waging war against the exploiting classes" (Mackenthun 2004,140 ) by redistributing the wealth of the colonies. Piracy, for Philip, signifies a just rebellion, a private, legitimate war against colonial exploiters and economic inequality-he repeatedly invokes their solidarity as misfortunate outcasts, indeed as the "wretched of the earth," as Frantz Fanon would later call them (see also Mackenthun 2004, 146). To the colored pirate, the pirating of goods is considered just as legitimate, perhaps even more legitimate, than the pirating of human beings: 
Because organized piracy presumed its own values, bespoke a particular kind of autonomy on the part of the pirates, validated a sense of courage in the pirates' undertakings, and cultivated a righteous indifference toward official society, Philip found it a fitting vehicle to carry forward the slave's sentiments about his condition. Because organized piracy inverted the notions of justice sanctioned with the civil state-that is, the purported respect for private property (which includes slaves) -it offered Philip an apt metaphor to advance an alternative system of values that differed from that of the slave-owning class. In other words, while the slave-owning class robbed Africans of their lives ..., the pirates robbed the slave-owning class of its illusions about their system and themselves and sought to destroy them at any cost. (Cudjoe 1997a, 257)

This aptness of organized piracy as a metaphorical vehicle to advance humanitarian values forbidding the enslavement of human beings leads Philip to the anachronistic representation of the buccaneers as Appadocca's allies and the "machinery" of the text, as the preface states (Philip [1854] 1997, 6). Philip might have known Exquemelin's Zee-Roovers (1678), which underwent various reprints and was widely available in the Americas and in Europe; as "buccaneers" became a generic term for pirates, Philip might not have made any distinction here; but his choice of the word boucaniers in the subtitle draws a parallel conflict between a colonial empire and its subalterns: first with regard to the predominantly poor settlers driven to piracy and to native peoples on the verge of genocide in the seventeenth century, and second, regarding disenfranchised African Americans in the nineteenth.

It is therefore remarkable that Philip blends various historical contexts in his representation of the boucaniers: the novel tells us that they are quasi-aristocratic exiles disgusted with the 1789 French Revolution (rather than banished Huguenots and escaped servants in the 1600s), while their society is paradoxically described in analogy with Exquemelin's 1678 account: "The French revolution had torn up whole families together, from the soil on which they had been rooted for generations, and had driven them to distant countries for protection and subsistence. They had carried with them, to their new homes, a strong hatred for their then democratic country, in particular, and for the whole world in general" (Philip [1854] 1997, 109), the pirate captain recounts, thus contradicting his description of life aboard the pirate ship, which is made up by subjects of various nationalities (most notably French, Spanish, and English). We meet them as Gregoire, José, or Jack, to name but a 
few, and their manners are all but aristocratic. That Appadocca describes "those boucans" as his "fellow students of the French University ... belonging to the old aristocracy" (110) is a significant anachronism. Still, for Philip, "boucanier" is better apt than "pirate" in the title because revenge is the driving force of the plot as it specifically refers to an historical phenomenon in the Caribbean the narrative thus evokes, since the foundational motives for the original buccaneer associations were defense and revenge against the Spaniards. In contrast, fictional pirates, by the 1850s, would have triggered less serious connotations in Philip's readers as they were usually associated with cheap novelettes (such as Lt. Murray's) and the popular stage, associations Philip certainly wanted to avoid with respect to the gravity of his subject matter.

\subsection{4 "A Literature of Revenge"}

The leitmotif of revenge as the multiracial pirate's prime motivation also refers to a different aspect of the Atlantic contact zone, namely the meeting and mixing of different cultural traditions and hence also of different understandings of legality and right. In this context, Appadocca's interpretation of the lex talionis, the right to revenge, is, in Cudjoe's words, that "this theological law is an integral part of ancient Africa's philosophical and theological system ... even though Europeans came to associate it with Hebraic Law. He [Appadocca] suggests that this African theological borrowing was applied incorrectly within the JudeoChristian system" (Cudjoe 2003, 126). Ancient cosmic laws provide him with philosophical legitimation for his actions because he is unable to find justice under colonial law; his only confidence is that God's justice is solely attainable through the human execution of cosmic and "natural," positivistic laws (Mackenthun 2004, 145). Voicing his marginal perspective with the help of natural rights philosophy, Appadocca deems this approach as a necessary ethical bulwark against the immoral capitalist materialism characteristic of the Atlantic triangle: "commerce makes steam engines and money-it assists not the philosophical progress of the mind," he says (Philip [1854] 1997, 116). Thus, Emmanuel Appadocca partakes in what Derek Walcott called the Caribbean predilection for a "literature of recrimination and despair, a literature of revenge written by the descendants of slaves or a literature of remorse written by the descendants of masters" (quoted in Smith 1999, 166). 
The question of descent, particularly of the "descendant of the master" (Smith 1999, 166), is of special importance for the questioning of dominant discourses of legitimacy in Appadocca; while Philip refines his protagonist with an aquiline nose, light complexion, and intellectual abilities and thus seems to deny the African component in favor of the native and Spanish element (present in Appadocca's looks and name), an "Africanist presence" (Morrison 1992) pervades the narrative in a number of respects and hence emphasizes the importance of the Atlantic as a contact zone. Faith Smith argues that this presence in Appadocca caused "particular kinds of anxieties" $(1999,175)$ in nineteenth-century Trinidadian literature, disturbing nationalist discourses. Yet the novel is less concerned with the striving for a national (black) literature of revenge-after all, Trinidad, at this time, "was a place where racial oppression was less entrenched than in other colonies" (176) - but rather voices a transnational, diasporic appeal to justice by a creole child of mixed heritage on behalf of all 'illegitimate' children and their mothers, imprisoned by the racist and class structures of the Atlantic world.

In the context of this chapter, what is most significant is the fact that Captain Appadocca combines ancient African knowledge, especially Egyptian astronomy and cosmology, and his western schooling not only in his legal rhetoric but also in the very act of navigation. His nautical skills, based on his astronomical and mathematical abilities, are described as superior knowledge throughout the book. "In its disguise of astronomy (representing ancient civilization), then, the theme of Africa is central to a novel which almost completely bypasses the topic of race" (Mackenthun $2004,144) .{ }^{24}$ The qualities of the Black Schooner are particularly significant here. Aboard deck we find "[t]he strange vessel"'s color inverted: "The long level deck was scoured as white as snow; not a speck, not a nail-head, not the minutest particle of anything could be discovered upon it. ... [T] he tapering masts were as clean and as smooth as ivory ... . An awning, as white as the deck which it sheltered" (Philip [1854] 1997, 20); also, everything is marked by the pirate emblem of a human skull "placed on the crossing of two dead men's bones." Metonymically, the ship stands for both its captain and crew, then: it is/they are black and white both, it is/they are a product of Europe, Africa, and America, it is/they are illegitimate, always already marked by society's death sentence and thus need to remind themselves of the imminence of death and the temporality of life. Life aboard is described as guided by these principles: there is much feasting and merrymaking when there is time, for instance during the 
"pleasure days" Appadocca allows; but as soon as the ship and the crew is endangered, firm discipline and obedience reign the ship. Thus, following Lennox, carnivalesque periods are granted as a safety valve (qua Bakhtin) to ensure discipline, though they also represent a discourse of critique "to promote an anticolonialist agenda" $(2017,2)$.

Compared to the Navy ships in the book, the pirate ship is depicted as far superior in its technological equipment, efficiency, speed, and navigation; in fact, it seems to be infused with almost supernatural power reminiscent of Jules Verne's Nautilus (which Verne envisioned fifteen years after Philip designed the Black Schooner). The vessel is introduced as

a low, black, balahoo schooner, whose model ... was most beautiful. She was built as sharply as a sword, with her bows terminating in the shape of a ... lance, while her stern slanted off in the most graceful proportions. But the most remarkable part in her build, was her immense and almost disproportionate length, which, combined with her perfectly straight lines, low hull, and the slenderness of her make, gave her the appearance of a large serpent. ... Her position also, and the manner in which she seemed moored ... was strange and peculiar. She was not swinging to the wind or current, but she rode under a bow and stern anchor, which kept her head directly towards the Dragon's Mouth, while the rippling waves ... broke playfully on her side. (Philip [1854] 1997, 18)

The schooner is in harmony with the ocean's natural forces (and thus the positivist basis of natural law doctrine), eventually directing these natural forces as if on her Captain's behalf to bring Willmington to his end when she sinks in a hurricane. In symbolic union with the protagonist, the ship uses the forces of nature (wind and waves) more efficiently than her enemies, as Appadocca draws on his knowledge of the natural sciences (astronomy, mathematics, optics, and even electronics) to surpass his powerful combatants. The ship employs a system of optical deception by using mirrors and natural light to keep her enemies within sight:

From the tall masts of the schooner, there were reared to an immense height into the air long poles of steel that were joined and joined again to each other ...; at the top of these were adjusted large globe-shaped metallic mirrors, that were filled with a thick white liquid, which was continuously agitated by a small electric engine, which received its power from a battery on deck. These mirrors, when the sun was at a certain height, were made, 
by a trigonometrical principle, to receive impressions of objects that were beyond the scope of the human eye, and by conveying those impressions to other mirrors, that were fixed in a thousand different ways, to the several parts of the vessel, gave the power to an individual on deck to see every movement of any vessel which would otherwise be invisible, while his own remained unseen. (193)

Optical inversion makes the pirate ship superior in strength "by the force of the same genius Appadocca was enabled to excel, to be unapproachable and irresistible" (193). The ship is portrayed as a Foucauldian heterotope of compensation: peaceful social relations aboard, with Appadocca reigning like a benevolent patriarch over his piratical crew:

The firmness of mind which enabled him to curb the natures of even pirates, and to establish a discipline on board the Black Schooner that made his men simultaneously act as if they were but the individual members of only one single body moved but by one spirit, might ... have procured for him the reputation of a wise and great leader; the powers of invention, which supplied even the deficiencies of human nature, and permitted him to make almost every element his servant, could again have handed down his name to posterity as that of a profound philosopher ... . It is not Emmanuel Appadocca alone that has been thus doomed to bury a high intellect in obscurity, or been impelled by circumstances to expend its force in guilt .... . (193-94)

Philip's description is reminiscent of the Hobbesian ideal state, the collective body of the Leviathan that is moved by a single spirit. It points to the waste of human (creole or mixed descent) genius and intelligence through an unjust system of colonial oppression and racism that bans the 'illegitimate' subject from official society directly (through laws of disenfranchisement, such as in the United States of the time) or indirectly (through uneven economic distribution and opportunities, as in Appadocca's case).

As a transatlantic cultural broker, Appadocca brings into dialogue western and African philosophical traditions rather than uncritically adopting dominant western perspectives guiding legal and scholarly discourses. Much could be said about the romantic subplots and the role of gender in Emmanuel Appadocca; much more analysis would be needed to spell out its protagonist's philosophy and reasoning. My main point in 
this chapter, however, is that the pirate ship is emblematic in its heterotopian embodiment of the ideal state, a harmonious social body that is possible and secured only through the captain's hybrid knowledge and the transnational, trans-ethnic solidarity of the "wretched outcasts" (93) of the Atlantic contact zone.

Yet, this heterotopia is at the same time implicated in dominant racist and gender discourses; Jack Jimmy, the black "sorceress" Celeste, equally stereotyped, as well as the absence of women from the ship (if not from the narrative) is significant in this respect. ${ }^{25}$ Focusing on the book's carnivalesque elements, Lennox argues that the racist and classist construction of the figure of Jack Jimmy proves that Philip "problematically uses carnival to advance the interests of the brown elite at the expense of the black working class" $(2017,13)$ at the same time as these elements are used in a discourse of a Black Atlantic countercultural resistance. In addition, the ship's alternative, more perfect social order is short-lived and thus does not offer a permanent structure on which a more equal and just Atlantic world could be based. In the literature of piracy and slavery, this imperial and resistant site is not designed as a clear-cut entity with fixed borders, but rather as a fluid, permeable contact zone, a site of conflict and struggle emanating from the antithetic experiences of the Atlantic triangle. In this context, it is significant that Appadocca and his buccaneers do not envision any territorial existence by their own values and "sought no other shelter than that which was afforded us by the high and wide seas" (160), knowing the conditionality of heterotopic space. ${ }^{26}$ The pirate ship and the sea emerge as counter-sites that, because of their very distance to "the law of the land," are privileged both in the development of social critique and the negotiation of cultural difference:

Appadocca's assertion of a postnational, indeed 'oceanic,' identity, coupled with the fact that he and his pirates never reside on land ... characterizes Emmanuel Appadocca as a multicultural, polyphonic, 'Atlantic' book ... . Philip inscribes the Atlantic Ocean as a site of 'natural' resistance against all forms of oppression, exploitation, and paternal disavowal ..., a multicultural contact zone which witnessed the most intense experiences of horror while holding the no less intensely felt promise of human equality and freedom which was unattainable on land. (Mackenthun 2004, 145-46)

That the pirate's mobile, temporary home has to remain beyond the Caribbean shores is both evidence of an emergent counter-modernity 
informed by the Black Atlantic and the tragedy of Philip's text. In the nineteenth century, the heterotope of the pirate ship thus helped Black Atlantic literature like Philip's to give voice to subaltern subject positions and allowed for a discursive questioning of the dominant order, even though the design of a 'more perfect' place from the perspective of the oppressed remains unstable.

\subsection{Piracy and Crises of Perception and Narration in Herman Melville's "Benito Cereno" (i855/I856) 27}

\subsubsection{Text and Contexts}

I have argued in the preceding chapter that during the slavery crisis of the mid-nineteenth century, piracy signified the criticality of legitimacy in the context of Black Atlantic narratives like Emmanuel Appadocca. Turning to a tale that has also been associated with the Black Atlantic (e.g., Mackenthun 2004, 113-40), I am reading Herman Melville's novella "Benito Cereno" (published as a tripartite serial installment in the popular Putnam's Monthly Magazine in 1855 and republished, slightly revised, as part of The Piazza Tales, in 1856) in this chapter in terms of its deconstruction of piracy as a potential Black Atlantic discourse of resistance. Like Philip's novel, "Benito Cereno" presents the ship as a site of instability, and the novella's conclusions are similarly governed by negativity. Commenting on the institution of slavery and the transatlantic slave trade, "Benito Cereno," as critics have suggested, allows no vision of liberation for either slave or master-not even for the U.S.-American protagonist, Amasa Delano, a Northerner who turns out to be complicit with the institution of slavery.

Though "Benito Cereno" has long been canonized and is valued for its complexity and aesthetics across many subfields of American Studies, from gender and queer to race criticism and New Americanist approaches, it is important to recall in the context of this study that Melville relies on a number of popular contemporaneous genres, "an array of formula plots designed to divert our attention." A "compendium of popular fiction" (Haegert 1993, 33), the novella takes up sensational elements from melodrama (masked relationships, disguised identities, dangerous encounters, last-minute escapes; 26), the sentimental novel, Gothic fiction, the detective story, ${ }^{28}$ and adventure narratives (23). This has led earlier critics, 
from Melville's own period to F. O. Matthiessen, to charge "Benito Cereno" with a superficiality and melodramatic excess that foreclosed racial sensitivity (Haegert 1993, 23-24). The novella's theatricality has been read by earlier Americanists as responsible for his insensitivity toward slavery rather than as constitutive for its epistemological disassemblement of the white and black, master-slave relationship. ${ }^{29}$ My reading follows more recent deconstructive interpretations, arguing that it is racial insensitivity as much as epistemological insecurity that governs Melville's language and that the tale presents a critique of popular sensational forms that leave no room for "moral ambiguity and ideological complexity" (Haegert 1993, 34; Zagarell 1992, 131 on Delano's sensationalist rhetoric).

The story, set in 1799, follows Captain Delano and his crew on the Bachelor's Delight as it encounters a battered-looking ship, the San Dominick. Boarding the ship, Delano is greeted by white sailors and black slaves who are begging for supplies. Always inquisitive, Delano wonders about the mysterious atmosphere and notes the concealed ship's figurehead, revealing only the inscription: "Follow your leader." Delano encounters the Spanish captain, Don Benito Cereno, constantly attended by his personal slave Babo, who does not part from his master's side even when Delano requests privacy with the Captain. Cereno claims that the ship has undergone much hardship, including terrible storms and the death of the slaves' master, Don Alexandro Aranda, who is said to have died of a fever. Delano becomes increasingly suspicious as he notes Cereno's dizziness and anxiety, the crew's strange movements and whisperings, and the unusual interaction of white and black aboard, subsequently vacillating "between dark suspicion and paternalistic disdain of the Spaniard" (Sundquist 1986, 109). After his crew drops off a few supplies from the Bachelor's Delight, Delano prepares to leave when suddenly Cereno jumps overboard, pursued by Babo, dagger in hand. The canvas falls off the ship's figurehead, revealing Aranda's skeleton replacing a Columbus figure. A battle initiated by the slaves erupts and turns against Delano's crew, who stop Babo from killing Cereno and eventually capture the San Dominick's black insurgents.

In a second part, often collapsed into the first, ${ }^{30}$ an omniscient narrator follows the crew of the Bachelor's Delight, without Delano, in pursuit of and eventually capturing the San Dominick. The tale then recounts, by means of a legal deposition (which entails Benito Cereno's perspective, Karcher 1980, 129), what happened on the San Dominick: that the 
black slaves mutinied and killed Aranda while keeping the crew, including Cereno, alive, since they needed them to sail to a free "Negro country" (ultimately referring to Africa). The captain directed the ship, in no shape for another transatlantic journey, toward the coast, hoping for rescue (while claiming to seek additional supplies). When the Bachelor's Delight came into view, the slaves hid Aranda's body and told the sailors to be quiet on threat of death. The ship's scenery, with Cereno as Captain and Babo as personal slave, turns out to have been a mere masquerade, staged by Babo. In the third section, an omniscient narrator comments on the deposition and finally, a final section follows Cereno and Delano to Lima and includes a report about the trial and execution of Babo as well as Cereno's own death little later. In closing, Delano ponders about how Cereno, in a role reversal as Babo's slave, followed by the death of one and then the other, indeed seemed to "[f]ollow [his] leader" (Melville [1855-1856] 2002, 102). ${ }^{31}$

With regard to the tale's historical context, Harold Scudder discovered, in 1928, that Amasa Delano was in fact an historical captain whose A Narrative of Voyages and Travels in the Northern and Southern Hemispheres Melville took as the basis for his tale. Delano recounts how his ship Perseverance encountered the Spanish Tryal, a ship whose slaves had overthrown the Spanish sailors; Melville rewrote Chapter XVIII of the Narrative and included a portion of one of the legal documents appended there, omitting some passages but also making additions (Scudder 1928, 502 ) for the deposition. In addition, he changed the year from 1805 to the "crisis year of 1799" (Levine 1989, 213), the year of Toussaint L'Ouverture's triumph in the Revolution of Santo Domingo (Haiti) and of fears of slave uprisings and "black empires" throughout the Americas triggered by this event (Sundquist 1986, 95-96; Levine 1989, 168-70). ${ }^{32}$ The year of "Benito Cereno"'s publication also marks the heyday of the slavery crisis - embodied politically by the Fugitive Slave Act and its "silencing effects" (Goldberg 2009, 7) on sympathizers of abolition and by the Kansas-Nebraska Act (1854), and culturally by Harriet Beecher Stowe's best seller Uncle Tom's Cabin (1852; Tawil 2006, 204). The half-decade, from 1850 to 1855 , coincides with F. O. Matthiessen's periodization of what he famously termed the "American Renaissance," an "extraordinarily concentrated moment of expression" (1941, vii) that concurs with this peak moment in the slavery crisis. "Benito Cereno" comments on this climactic moment of the crisis (Sundquist 1986, 94). To a certain extent, it also reenacts the Amistad case, in the context of 
which John Quincy Adams invoked the Declaration of Independence to justify slave revolt at sea in terms of the natural right to liberty and revolution and to dissociate them from piracy (Rogin [1979] 1985, 211). ${ }^{33}$ Territorial, positive law, abolitionists argued, especially did not translate to non-territorial waters. In the case of the Amistad, Justice Story asserted that as much as the slaves might have committed dreadful acts, "they cannot be deemed pirates and robbers in the sense of the law of nations" (quoted in Rogin [1979] 1985, 212); for him, any slave ship was a pirate since the moment the slave trade became illegal in international law. The Amistad case strengthened and further inspired discourses that saw the topics of piracy and slavery in need of disentanglement or reversalthe slavers rather than mutinous slaves needed to be unmasked, from the abolitionist perspective, as the real pirates. These widely reported legal arguments were articulated and commented upon in "Benito Cereno" as well as on the popular stage, for example in the widely successful nautical melodrama The Black Schooner or the Pirate Slaver Armistead or The Long, Low Black Schooner, as it was more commonly called, opening in the Bowery Theatre of New York three days after the Amistad Africans arrived at the New Haven prison in 1839 ("an entire new and deeply interesting Nautical Melo-Drama, in 2 acts, written expressly for this Theatre, by a popular author," so the playbill quoted in Rediker [2012, 114], most probably Jonas B. Phillips, the Theatre's house playwright). ${ }^{34}$

With regard to the role of the ship in "Benito Cereno," the San Dominick confronts three historical positions (Karcher 1980, 136): Old World (Columbus' figurehead, notably replaced by the blacks with the skeleton of Aranda; Benedict de las Casas, responsible for the introduction of African slavery as a workforce in the New World as well as the Spanish Inquisition, echoed in the name Benito and the evocation of Black Friars (Melville 36); Benito Cereno himself, physically weak, impotent, and mentally unstable, not coincidentally also evoking the abolitionist image of "the haunted Southerner," Karcher 1980, 136) ${ }^{35}$; African (Babo and his fellow enslaved mutineers, subjects that have undergone the process of dehumanization and commodification and are in a state of historical transition, entering the American hemisphere), and New World (Delano's, conflating it with Anglo-America). In this, "Melville's tale ... anticipates ... an explosive resolution of the conflict between American democracy, Old World despotism, and [black] New World revolution" (Sundquist 1986, 106) and disturbs contemporary assumptions about law and legitimacy based on a stable order of signification: 
If the figurehead of "Christoph Colon" represented the discovery and conquest of the New World ... and ... the faith in the destiny and direction and above all the Right of European projects, the replacement does not simply oppose that message with a skull and crossbones in the matter of the mere outlaw or pirate but fundamentally deposes the order of signification it represents. (Robinson 2014, 144)

A traditional allegory for "America as a federated 'ship of state" (Levine $1989,191)$ and, in the context of the 1850s' crisis over the future of the United States, for the Union as such, the San Dominick displaces this national(ist) allegory with the emergence of modern transatlantic cultural mixture; in this, the tale co-constructs a Black Atlantic counterculture (Reichardt 2001, 128, following Gilroy). In contrast to the ideal Unionist antebellum sea narrative, in which the ship was ordered hierarchically and structured by familial relations "containing a kindly paternal captain and a willingly submissive childlike crew" (Levine 1989, 167) in "perfect sea order" (Richard Henry Dana, quoted in Levine 1989, 176), the ships in "Benito Cereno" are in bad shape: either economically unsuccessful and pressured by expectations of material gain (the Bachelor's Delight) or in a state of disarray (the San Dominick), confronted by mutiny, piracy, and revolt. ${ }^{36}$ "[D] econstruct[ing] the fables of utopian discourse" (Mackenthun 2004, 120), the text creates the San Dominick as perhaps the prime example of heterotopian spatial imaginings within the interpretive framework of my study, presenting a radical disruption and reversal of conventional order, most notably in the use of split signifiers in the famous shaving scene. ${ }^{37}$ In what follows, I explore how "Benito Cereno" enacts epistemological crisis through such and similar literary techniques as well as through the tale's continuous evocation of piracy.

\subsubsection{The Gray Atlantic: Narrating Epistemological Crisis}

Maggie Montesinos Sale notes that the structure of "Benito Cereno"

purposefully suspends sure knowledge of the San Dominick's history, thereby generating an unsure sense of reality, symbolized by the mist shrouding the San Dominick or the unbelievably complex Gordian knot ... In this way, [it] produces anxiety within its readers, not only about the outcome of the story, but about the reliability of the characters, and ultimately, about their/our own perceptions. $(1997,154)$ 
Melville's primary techniques to achieve this effect rests with the form of the collage of different textual materials and discourses as well as narrative perspectives, foreshadowing modernist literature. The first of the four parts into which "Benito Cereno" is structured introduces an auctorial narrative perspective, which, however, soon narrows down to Delano's as he becomes the main focalizer of what has been called one of the earliest examples of a figural third-person text. ${ }^{38}$ Yet the fact that signals of auctorial narrative intervention persist results in a pervasive tension between Delano's figural perspective and the auctorial narrative voice, producing moral confusion and interpretative irritations in the reader (Schnackertz 1993, 168): it is often unclear who is speaking, whose voice and judgment are being witnessed; in this way, Melville breaks the text's contract with his readers, tossing them off their epistemological grounds of reasoning. The narrative frame thus constantly distances the reader from Delano's ideas (Kavanagh 1986, 357), which, in addition to his character as a whole, are revealed to be highly naive. He reverts each suspicion of evil to comfortable explanations; hence Delano's strategies of familiarization stand in stark opposition to the narrator's strategies of defamiliarization (Reichardt 2001, 127), which, together with an imagery that often contradicts his racial ideas (Mackenthun 2004, 118), further adds to the tension evoked. Taken together, all of these textual features result in an extreme case of an unreliable narrative situation.

The device of a "deluded" and "uncomprehending" protagonist and focalizer "who entirely misses the significance of what he witnesses, situates the principal interest of the tale" (Kamuf 1997, 184) and a narrator displaying much skepticism toward the protagonists' perceptive abilities clearly characterizes the narrative as supremely concerned with epistemology and processes of knowledge-formation: its focus is "not on the products of knowledge, or answers, but on the process of knowledge, on the way the mind reaches its conclusions" (Roundy 1978, 345). Consequently, questions of (racial) ideology and (mis-)perception, of identity and performance/appearance, of the value of different textual discourses (especially literary and legal), and of power/knowledge and (mis-)communication are at the fore of "Benito Cereno"'s epistemological examinations. Delano's epistemological limitations also translate to the reader, who encounters the plot through this radically limited point of view, mostly in free indirect discourse that renders protagonist and narrator virtually indistinguishable and "makes of the unsuspecting reader 
an accomplice" (Kamuf 1997, 184). Through this narrative stratagem, the reader is lured into the American captain's racist preconceptions, with the San Dominick by appearance denying all certainty in terms of knowing and telling. As many critics have noted, Delano's inability to understand what is going on around him is predicated on the prevalent racial ideology of a "natural order" that he is subtly exposed to articulate in the course of the narrative (Sale 1997, 159): though a Northerner, Delano is complicit in the slave trade for example when he offers to buy Babo, but also when he thinks about selling the slaves for his and his crew's own fortune (Karcher 1980, 128-59). Furthermore, he is culturally blinded by an Atlantic world which by definition is "hostile to any fixed notions of national or racial identity" (Blum 2006, 122). Delano, stating that he faces the Spaniard's "black-letter text" (53),

is unable to credit what he reads in clear black letters: the black authorship of the very plot he is acting out, his role written for him in advance by the slave whom he takes to be a savage illiterate. He read black on white, but he still chooses to see white on black, white over black, and credits the latter since it alone fits the larger cultural text. Delano's credulity is tested by these contradictions, but it always rebounds by virtue of the faith he has in the "natural" order of white over black. (Kamuf 1997, 185)

Neither the historical nor the fictional Delano ever question the legitimacy of slavery and the "natural order" it was based on (Stuckey 2009, 54), highlighting the "incapacity, even among abolitionists, to perceive the full humanity of Africans, including their capacity for self-defense" due to a pervasive "benevolent racism" (Mackenthun 2004, 115-16) which is erased upon being attacked by the slaves. Delano responds to the shock of the attack with a violence that protects him from trauma (Rogin [1979] 1985, 218) and leaves him, unlike Benito Cereno and unlike the reader (who at that point does not trust Delano's perception anymore), unaffected by his experience of the uncanny (Freud). It is Delano, then, rather than the Africans, who is illiterate in this scenario, and with him the reader, as the narrator "seeks to draw the (white) reader into the very illusion presented by Delano" based in both respects on the "general white stupidity about race relations" (Kamuf 1997, 188). Indeed, it turns out that Babo had Cereno sign a contract in which the captain promised to return the Africans to Senegal; unlike many of the Spanish sailors, Babo 
can write. Furthermore, the effect of Delano's narrative status as focalizer combined with his misperceptions places the focus on the problem of reading and literary communication (Tawil 2006, 197).

Even the second part, the legal deposition included in the text, provides closure only at first glance. The implied author-narrator, before "go[ing] into eclipse" (Kamuf 1997, 184), prefaces the deposition with a plethora of disclaimers regarding its limited potential to reveal the truth of the matter:

The following extracts, translated from one of the official Spanish documents, will, it is hoped, shed light on the preceding narrative ... . The document selected, from among many others, for partial translation, contains the deposition of Benito Cereno .... . Some disclosures therein were, at the time, held dubious for both learned and natural reasons. The tribunal inclined to the opinion that the deponent, not undisturbed in his mind by recent events, raved of some things which could never have happened. But subsequent depositions of the surviving sailors, bearing out the revelations of their captain in several of the strangest particulars, gave credence to the rest. So that the tribunal, in its final decision, rested its capital sentences upon statements which, had they lacked confirmation, it would have deemed it but duty to reject.

These cautionary remarks emphasize the subsequent text's fragmentation: its selection by an implied author the reader has learned to distrust at this point, its partiality and translation, and, last but not least, Don Benito's mental state as the main witness, all of which severely inhibit its potential of closure and, on another level, reveal the epistemological limitations not just of literary, but also of legal and legislative discourse and procedure, relying upon the same tropes and rhetoric (Sale 1997, 152). ${ }^{39}$ The text's judicial uncertainty (Thomas 1987) suggests that its silences and ambiguities "do not offer gaps to be filled by a source text so much as reflect the gaps that institutional sources themselves proliferated" and hence represents "justice's perversion as an archive of silence, empty of the content it is expected to hold" (Goldberg 2009, 7) as Babo, "[a]s a matter of law," is prohibited from testifying in his own defense-again, both in the literary and the legal texts of "Benito Cereno." In Susan Weiner's words, the novella thus also explores how the law, as well as a legal reasoning that "posits a realm of knowledge that is objective, clear, and readily accessible," "fails to find legal solutions to critical crises" regarding the truth in the San Dominick case $(1992,117 ; 115)$. 
From Babo's perspective, this silence signifies "a final gesture of mutinous resistance" within the text, "not only against his colonial masters, but even against an imperialist author who would appropriate him further" (Haegert 1993, 37); a mutinous act that is also piratical, I would add, resisting metaphorical expropriation and incorporation into literary structures of meaning-making. The radical denial of closure can also be viewed as self-reflexive in this context as a final break from all the popular formulas "Benito Cereno" invokes (34): commenting on the "authoritarian impulse of all narrative" in this way, the novella "also dramatizes the subversive and illicit movement of meanings not included in its teleological grip" (36).

The deposition cannot solve the narrative's mysteries since it is further appended by a flashback, presenting the final conversation between Delano and Cereno ("as if there were some reluctance to leave the final word to the state-appointed court of judgment, even as it has to concede that the law will rule in any case," Kamuf 1997, 184). (Un)Don(e) Benito, in a state of what today might be called Post-traumatic Stress Disorder, has the final word, resulting in the most-quoted passage of the tale; after Benito's utterance, the narrator can merely comment upon the silence that follows, before he, too, gives up and leaves the reader without closure. Taken together, this organization of the tale presents what Peggy Kamuf calls a model of the literary text as a "self-canceling structure of repetition" (198), as the readers' expectations concerning the truth are repeatedly nursed but never met.

In terms of narratology, "Benito Cereno" leaves the question whether the third-person narration is entirely extra- or intradiegetic undecided, this indecision "wavering between confidence and suspicion, faith and mistrust" (Kamuf 1997, 194). The indeterminacy that characterizes the tale indeed follows the text beyond its plot, as an instance of "Narrative Mutiny" (Haegert 1993, 21) ${ }^{40}$ and is fundamental for the tale's suggestion that not only does the forced entry of Africans into western history result in a plurality of perspectives, but also in a pluralizing of history itself (Reichardt 2001, 140, 148-52). The polyphony of narrative and figural voices and the text's use of double entendres (Tawil 2006, 202) creates a "double-voiced trickster narrative" (Mackenthun 2004, 117) playing with cognitive dissonance and complemented by the prevalent suspicion of piracy.

The tale's imagery adds another dimension to "Benito Cereno"'s literary enactment of epistemological crisis. The color imagery centers 
on the color gray, mentioned four times already in the description of the atmosphere in the opening paragraph: "Everything was mute and calm; everything gray ... . The sky seemed a gray surtout. Flights of troubled gray fowl, kith and kin with flights of troubled gray vapors among which they were mixed, skimmed low and fitfully over the waters ... . Shadows present, foreshadowing deeper shadows to come." The events are rendered in terms of ambivalence as grayness "envelops the appearance of the mysterious San Dominick" (Mackenthun 2004, 117; Nnolim $1974,57)$. The importance of the color gray and of shadow imagery"the Negro ... an absence that casts a shadowy presence" (Levine 1989, 222) — marks the tale as "the shadow play ... of America's own balked Revolution and its ensuing domestic turmoil" (Sundquist 1986, 104); in a similar vein, Michael Rogin remarks that " $[\mathrm{t}]$ he shadow cast by the Negro over Don Benito is not just the specter of revolt; it is also the stage play of shadows detached from their bodies which has drained the life and color out of his human ties" ([1979] 1985, 215), mistrusting patriarchal domestic relations that constitute the slave's identity. ${ }^{41}$ The central epistemological metaphor is of course the "Gordian knot" Delano observes in the hand of an old sailor:

Delano stood in silence surveying the knot; his mind, by a not uncongenial transition, passing from its own entanglements to those of the hemp. For intricacy such a knot he had never seen in an American ship, or indeed any other. The old man looked like an Egyptian priest, making gordian knots for the temple of Ammon. The knot seemed a combination of doublebowline knot, treble-crown-knot, back-handed-well-knot, knot-in-and-outknot, and jamming-knot.

Delano is asked by this sailor-another ambivalent figure associated in identity both with the Spanish crew and with the Africans (in his resemblance of an "Egyptian priest") — to "[u]ndo it, cut it, quick" (63), but Delano- "knot in hand, and knot in head"-is unable to break it. Ultimately, the mutineering slaves themselves, organizing the state of exception (Reichardt 2001, 139, qua Giorgio Agamben) aboard the San Dominick, throw the knot overboard. In light of this central metaphor, Melville's tale presents a "crisis-ridden work that winds around on the strands of America's Gordian knot and asks of even its most enlightened readers to participate with Delano, however unwillingly, in the anxious 
and blinding desire for 'perfect sea order' that could sanction so insidious an institution as slavery" (139).

"Benito Cereno" offers an epistemological model that demonstrates the precariousness of signification (Reichardt calls this postmodern avant la lettre, 2001, 127; see also Mackenthun 2004, 117), placing the reader between Delano and Cereno, "plagued by the limitation of our eye and the facts we can see, but also by the uncertainty of our imagination and the meanings it suggests" (Roundy 1978, 347). The text leaves its readers in a precarious epistemological state, a world of masquerade and shifting appearances even beyond its ending.

Mackenthun argues that the tale eventually "remains locked in a state of ideological stasis" and offers neither a "fiction of empowerment" nor imagines ways out of the conundrums of Atlantic slavery (unlike texts by black writers like Fredrick Douglass in the United States or Philip in the Caribbean); neither does it present "a vision of the reformability of the Euro-American racist mind" $(2004,24)$. In his new historicist reading, Levine similarly concludes that "Benito Cereno" demonstrates Melville's implication "in the containment strategies of his [racist] culture" (1989, 215 ). While a reading against the grain, emphasizing the tale's polyphony, certainly "places Melville at an ironic and critical distance from such strategies" and creates biting ironic reversals regarding slavery, piracy, and mutiny, Levine cautions that this "irony does not necessarily liberate the writer from the taint of implication" $(1989,215)$. Still, in its radical perspectivism and plurichronic temporal texture, "Benito Cereno"

not only exceeds other texts of the nineteenth century ... in that it textually deconstructs the assumption of homogeneity regarding Western, here specifically American, history and civilization, and thus contributes to the recognition of the plurality of experiences and interpretations of a history defined by the colonization of America, the triangular trade, and the ... emergence of an "Atlantic," culturally hybrid space, but ... also implicitly unmasks the conceptual costs of perspectivist ... thought. Melville's ... epistemological skepticism cannot be understood without his analysis of difference of civilization and race; his political critique, in turn, cannot be explained without the epistemological reflection. (Reichardt $2001,124-25)^{42}$

Moreover, the text's enactment of epistemological crisis, narrative uncertainty, and polyphony anticipates both postcolonial claims that the 
colonized cannot be represented as long as the power of representation rests with the colonizer (Mackenthun 2004, 125) and strategies of colonial mimicry (Homi Bhabha) enacted in Babo's heterotopian and "carnivalesque imitation of social relations" (116). In the following section, my reading of suspicion as the crucial device for the narrative's questioning of epistemological certainty-and hence its articulation of epistemological crisis in a Black Atlantic context-follows Haegert's claim that what is

fundamental to the work's subversive movement is a deep-seated suspicion of the dynamics of narrative itself. In this sense Benito Cereno is a work which challenges not only the authority of sea captains and judges, but even its own authority to speak for an enslaved other who has been denied any definitive voice in the world of the text. $(1993,32)$

\subsubsection{Suspicion, Repression, and the Kaleidoscope of Piracy}

As I have argued along with many other critics before me, the novella reflects the slavery crisis as fundamentally a crisis of knowing and telling, voicing ontological and epistemological insecurity. It does so, however, not only by its narrative construction, but also by showing that masters and slaves as well as pirates are arbitrary, reversible cultural concepts. The narrative invokes piracy as a suspicion without referent-a floating signifier. Its lack of determination regarding significants of piracy renders it a potent suspicion that cannot be confirmed ontologically.

Sterling Stuckey and Joshua Leslie (1988) were perhaps the first to focus on Melville's highly significant ways of evoking piracy in "Benito Cereno," complementing the novella and its historical source with archival documents from the Archive Nacionale of Santiago de Chile (they entitle the file, as well as their essay, "Aftermath: Captain Delano's Claim Against Benito Cereno"). ${ }^{43}$ Unlike Melville's, Delano's narrative explicitly includes the accusations of piracy against him in court, presenting them as a vile stratagem by the ungrateful Spaniards; these documents further elucidate this accusation and Melville's rewritings. Delano, for Stuckey and Leslie (along with most other contemporary critics), embodies a spirit of imperialism that, in search of wealth, reduces "moral scruples" to a mere "petty annoyance" $(1988,269)$ : they cite the deposition of Delano's crew member Peter Samson, stating that the crew "did not know whether, having wasted the voyage, the captain would practice piracy in order to meet the expenses of the expedition" 
and claiming that Melville's reversal of the charge, placing it upon the Spaniard, is "harsh," "almost shocking," "Delano's suspicions regarding Benito Cereno bordering on paranoia." In the original documents, it is Benito Cereno who calls Delano a piratical "monster"; Melville obliterates the charge and instead has Delano call Benito a murderer (271). Thus, "[b]asing the theme of piracy in the novella on the Peter Samson charge to which Delano refers but does not include among the depositions in Voyages, Melville extends the conflict between the historical Delano and Benito Cereno into the very heart of the novella"; Delano himself suppressed some of the documents available in the Archivo in recording the revolt and its aftermath (273).

To some extent, Melville's tale certainly concurs with that suppression, omitting accusations of piracy against Delano (see ch. 18 of his Narrative). Yet it is important here to distinguish between Delano's and the auctorial narrative perspective: in the parts that are told from Delano's unreliable and limited point of view, it is no surprise that he disassociates himself from any such suspicion: from the self-righteous, chauvinistic U.S.-American imperial trader's view, pirates are always the Other. A contrapuntal reading, however, reveals that even these parts are subtly casting Delano as piratical.

For one, Delano uses the same motivational rhetoric as the buccaneers and Caribbean pirates of the seventeenth century, a rhetoric of plunder that does not distinguish between gold, silver, and human "cargo": "The more to encourage the sailors, they were told that the Spanish captain considered his ship good as lost; that she and her cargo, including some gold and silver, were worth more than a thousand doubloons. Take her, and no small part should be theirs." As Mackenthun states, Delano's attack on the San Dominick "reveals him as a figure that spans the period from the history of seventeenth-century buccaneers to the more subtle piracies of the 1850 s" $(2004,123)$, representing him "less as an honorable merchantman than a privateer and pirate" (115, also Nnolim 1974, 17) whose chief mate, it is stated explicitly, also had been a "privateer'sman, and, as his enemies whispered, a pirate" (Melville 87: a fact not mentioned by Melville's source; see Emery 1992, 102). This presents one instance in which the text has the fictional Delano externalize the accusation of piracy faced by the historical Delano, who indeed worked as a privateer during the U.S.-American Revolution.

Melville's tale further associates Delano with piracy by renaming the historical Amasa Delano's ship Perseverance into the Bachelor's 
Delight, referencing William Dampier's pirate ship, a Danish slaver Dampier renamed. In 1683, he and his crew went to Guinea, became involved in the slave trade, and took a number of enslaved African women whom they subsequently raped and abused on the ship (Lane 2007, n.p.; Franklin 1992, 237; a fact Dampier conceals in his Narrative, see Sect. 2.1). In addition, Delano's boat is called The Rover, and though Delano references the vessel frequently when he seeks out a stable sign, reassured by its familiarity and metaphorically comparing her, like "the Negro" a little later, to a Newfoundland dog (64; Kamuf 1997, 193), its linguistic signification carries with it instability and fluidity. The dog metaphor evokes the English sea-dogs of the sixteenth century, and a rover demarcates mobility and inconstancy, the shiftiness of the sea and of ships themselves roving between various owners-slave-traders, merchantmen, pirates (Nnolim 1974, 18). By associating the enterprising U.S.-American captain with piracy, then, the text also implies that Manifest Destiny, epitomized on America's maritime frontier by the historical Delano and his filibustering peers (who attempted to expand the U.S. political sphere toward Cuba, Haiti, Central America, and the Pacific), is merely "the rhetorical camouflage for a largely 'piratical' enterprise" (Emery 1992, 103), invalidating the distinction between American expansionism and European colonialism. ${ }^{44}$ The characterization of Spaniards and Africans as potential pirates serves as another camouflaging strategy, a reversal by use of an ideological category to stereotype others (Zagarell 1992, 141) which externalizes illegitimacy and illegality, projecting it from the United States onto such Others:

Just as Delano projects onto Cereno piratical schemes that he himself will blithely - and with the best intentions-actually perpetrate, so the United States in the mid-nineteenth century was projecting onto the decaying Spanish empire images that would legitimize its own piratical—but of course well-intentioned-expansionism. (Franklin 1992, 238)

In this context, Brook Thomas's characterization of "Benito Cereno" as “Melville's Narrative of Repression" (1987, 93) points to these mechanisms of disassociation as well as to Babo as embodying the return of the repressed in the novella in both a political and Freudian sense (112), showing that Delano's pursuit of profit implicates him in illegitimate as well as legitimate activities (also Zagarell 1992, 140). 
The roving signifier of piracy renders the term an "unreliable trope[]" (Kamuf 1997, 193) throughout the tale. Hence Melville does not obliterate piracy as a potential status regarding the American captain but rather recasts it as a "kaleidoscopic question about who was the real pirate" (Mackenthun 2004, 113, quoting Jones; also Franklin 1992, 237; Beebee 2006, 128). When Delano is suspicious about, but refrains from interpreting, the amount of various national flags he discovers in a locker ("exposing various colored bunting, some rolled up, others half unrolled, still others tumbled," Melville 70), the reader familiar with earlier Caribbean pirate narratives which reported that buccaneers used flags of convenience, must read this discovery as a rewriting of Benito Cereno's trading in slaves as piracy.

The flags, cast together in disorderly manner, also function as a transnational metaphor for the messiness of the slave trade, acted out under all of these flags, and hence associating all of these European (and later American) nations with piracy. In Eric Sundquist's words, "Benito Cereno" highlights that "slavery was hemispheric and that its fullest literary representation as well as its fullest political critique required a view that embraced several cultures, several nations" (1986, 136). In this context, Babo's misuse of the Spanish flag as a shaving towel in the tale's most famous scene can be read as another reversal: the tale suggests that this misuse is much less criminal or "piratical," for that matter, than the slave trade committed under all of these "bright colors." Babo and his peers are similar to pirates in that the black slave is by law positioned outside the community of humankind, of "civilized," lawful nations, as the silent, barbarous, savage Other: "nothing done to them can be a violation of law" and "they therefore have no "natural' right to self-defense" (Sale 1997,161 ; it is noteworthy that the tale includes a stereotype of African behavior as barbaric and brutal not to be found in the historical Delano's source text).

Delano's earlier suspicion that the San Dominick "be of a piratical character"-he "nervously wonders why a ship sailing in a lawless part of the world should choose not to show its color" (Levine 1989, 200)—also displays the way his perception is shaped by a "benevolent racism," as he sees Spaniards as shady characters but Africans as "too stupid" to be the masterminds of a piratical scheme (Mackenthun 2004, 116), taking to them "not philanthropically, but genially, just as other men to Newfoundland dogs." 45 Thus Delano, blinded by the imperial conflict between the Spanish and Anglo Empires in the New World, at first suspects Cereno 
rather than the Africans to be potentially piratical, crying out in a double alliteration that "this plotting pirate means murder!" (84). Likewise, he is blinded by his self-righteousness and alleged innocence as a "Jack of the Beach" (64), musing: "I to be murdered here at the ends of the earth, on board a haunted pirate-ship by a horrible Spaniard? Too nonsensical to think of! Who would murder Amasa Delano?" (64); the "pirate ship" is a characterization that is in fact much more accurate with regard to Delano's ship (Franklin 1992, 237).

It is the black mutineers' use of a fine-tuned arrangement of deceptive behavior, the only available weapon to slaves, that subsequently associates them with the deceptive techniques of Caribbean and other historical pirates (e.g., in their theatrical mis/use of flags). In one of a number of suspicious moments, the narrator, through Delano, compares them to "the Malay pirates" for whom "it was no unusual thing to lure ships after them into their treacherous harbors, or entice boarders from a declared enemy at sea, by the spectacle of thinly manned or vacant decks, beneath which prowled a hundred spears with yellow arms ready to upthrust them through the mats"; that the comparison relates to Malay rather than Caribbean pirates references the historical Delano's New Guinea chapter, in which he recounts whites wanting to enter an area of New Guinea occupied by Malays, whose past experiences with white men (who had a history of abusing Malay women, for instance), makes them hostile toward such a landing (Stuckey 2009, 55). While the historical Delano argues with the Malays, the fictional Delano immediately suppresses his suspicions and sense of danger: "Not that Captain Delano had entirely credited such things. He had heard of them-and now, as stories, they recurred." Only upon being openly attacked at the climax of the action does the discourse of piracy return as he perceives the slaves, "now with the scales dropped from his eyes ... with mask torn away, flourishing hatchets, and knives, in ferocious piratical revolt" (85); his surprise at this turn of events indicates that he was "duped, perhaps more by his own perceptions than by the rebels' acting" (Sale 1997, 158). The novella's unveiling of black violence can also be read as exposing legitimacy as culturally constructed, as it

exposes the bankruptcy of Delano's romantic idealizations while at the same time-and this is the novella's most unsettling irony- "legitimizing" his, the captain-like reader's, and, eventually, the Spanish authorities' recourse to a containing institutionalism. In Benito Cereno Melville relates 
the 'peculiar institution' of slavery to the familial institution of the ship as part of a brilliant historical perception of the relationship between the legitimizing of racial and ethnic stereotypes and the legitimizing of institutions of social control .... (Levine 1989, 216)

Levine adds that the presentation of the revolutionary slave conspiracy as a mutiny is essential to "Benito Cereno"'s portrayal of the legitimation process, but it is also Melville's use of the disruptive, shadowy presence of piracy as a metaphor of epistemological dimensions throughout the tale that consistently points to questions of legitimacy and legality.

As Haegert notes, in the process of repeatedly suppressing suspicion about the power relations aboard the San Dominick, Delano "unfailingly asserts a cultural and racial hegemony which masks itself as a kind of natural law, even a theology of sorts" $(1993,34)$ as Delano time and again reverts to a blind belief in "the ever-watchful Providence," deemed to be on the side of its U.S.-American agents. In near-amnesia, he even forgets his worries about destruction when thinking of another visit below deck. His self-conception of innocence and legitimacy is constructed as an appropriation of Spanish colonial legacies, even if in an act of piracy (Schnackertz 1993, 179). This Puritan sense of mission, articulated also by presenting Delano as a figure whose "conscience is clean" is likewise exposed by Melville as an unjustified fiction, facing Yankee complicity with Old World orders (embodied by Cereno) and the institution of slavery (Schnackertz 1993, 177).

Delano's association with piracy suggests that U.S.-American victory and leadership (especially regarding global trade)-the tale's de facto results-originate in illegitimate piracy. This seems to be another age of revolution-hence Melville's alteration of the year this happened. By insinuating a parallel with sailing under an American flag that was not internationally recognized as legitimate during the Revolutionary War, the resurgent slaves, sailing under no colors, might become legitimate, even leading actors in the future of the hemisphere. This is reminiscent of H. Bruce Franklin's argument that the contradictions of the U.S. Revolution-that slavery continued beyond liberation from England-are acted out aboard the San Dominick (1992, 234).

The process of suppressing suspicion by way of familiarization and/or externalization exempts the suspicious character (whose point of view is dominant) from attracting suspicion himself. Delano fears that the slaves have turned pirate while in fact, as the text quietly suggests, his predatory 
intentions are themselves piratical (Blum 2006, 122) and his governance over the crew can be characterized as piratical leadership-again, not in terms of ontology but of performance, as he offers them equal shares of the prospective bounty of the San Dominick to motivate them for the battle.

In its construction of "transracial savagery" (Levine 1989, 220), then, "Benito Cereno" nihilistically suggests that both whites and blacks are potential pirates and slaves, and symbols of authority like flags and weapons easily appropriated. Legitimacy, authority, piracy, and slavery are all terms that the novella exposes as defined by conventional power relations rather than by nature. The result of the novella's radical dramatization of shifting appearances is thus truly an "epistemological nightmare" (Roundy 1978, 350) that fundamentally questions narrative authority and claims about legitimacy and truth. ${ }^{46}$

\subsubsection{From the Black Atlantic to the Bleak Atlantic}

Few critics have made anything of the fact that "Benito Cereno," grounded in the transatlantic slave trade, is in fact set on the Pacific Rim, thus anticipating the shift of actual piracy cases to the Pacific scenario toward the end of the nineteenth century (again concomitant with the shift of empire-building, this time U.S.-American, toward the Pacific). That the revolting slaves are compared to Malay rather than Caribbean pirates has not been discussed as significant in its anticipation of the violent imperial scenarios that would come to characterize United States-Pacific relations in that period. As Hester Blum notes, this of course does not mean that Melville's narrative is not still, thematically, Atlantic $(2006,120)$, the transatlantic slave trade "quietly govern[ing] the story." "Benito Cereno" is indeed both an Atlantic and a Pacific text (the latter being, after all, Melville's preferred scenario for his maritime tales), arguing that the institution of slavery and its specters knows no geographical borders. As Blum continues, the precariousness of national and individual sovereignty in the Atlantic world always already haunts the Pacific (122). Indeed, the Atlantic, through "Benito Cereno" and similar maritime texts of the antebellum period, becomes (also) metaphorical (Mackenthun 2004, ch. 5) as these narratives construct a globalized continuum of slavery and piracy. "Benito Cereno," directed at a cisAtlantic market (Buell 1992, 116), presents an "explicitly transnational fictional perspective ... for the negotiation of conflict lines, historical 
controversies and predicaments of U.S. society and culture" (Heide 2008, 37), its "hemispheric dimensions mak[ing] the novella a Pan-American literary endeavor" (43).

In this context, it is also noteworthy that piracy is introduced as a European phenomenon earlier in the Piazza Tales: with "The BellTower," examining the degradedness of slave society of sixteenth-century Venice, "Benito Cereno" forms a diptych structure in Melville's critique of slavery (Karcher 1980, 143). Submitted to Putnam's a few weeks after "Benito Cereno" but published before it in the magazine (157), it spans the topic of slavery back around the globe to its origins in European maritime states. Linked by Shakespeare's Othello and its rebellious African in Venice, the diptych presents a comment on the globalization of slavery (and piracy, for that matter, as the history of Venice is itself deeply entangled with piratical practices). ${ }^{47}$

The international context "Benito Cereno" draws on and the centrality of the figure of the pirate with regard to international law has attracted attention also by critics in that field. Most notably, the National Socialist Carl Schmitt, who also theorized piracy in a problematic land-versussea dichotomy (see Schmitt 1937, 1942), commented on the tale as a geopolitical allegory presenting the end of the jus publicum Europaeum, emphasizing the theme of piracy while entirely disregarding slavery (Robinson 2014, 140). Schmitt identified with Cereno, saying that he experienced the end of European political law in the face of economic globalization "like Benito Cereno experienced the journey of the pirate ship"- a hostage ("erfahre sein Ende so, wie Benito Cereno die Fahrt des Piratenschiffs erfuhr," 1950, 75, my transl.; Beebee 2006, 115, 120). With this metaphor, Beebee explains, Schmitt "alludes to the role of sea power in the dissolution of a historical legal order" (127) as he saw the age of piracy in the New World as a crucial phase in world history, with increasing sea power propelling the universalizing of law (128). He viewed piracy as both the foundation of the British Empire and of capitalism, yet blots out-represses-slavery altogether, sublimating it into piracy (129).

Schmitt's woe with regard to the end of European hegemony rather than the institution of slavery is one version of what I call the Bleak Atlantic that Melville's novella, a Gothic tale of haunting and enchantment pervaded by the imagery of death and ghosts and a deep sense of gloom, creates (Mackenthun 2004, 122). Reaching the Pacific, the Black Atlantic as a counterculture of resistance against Western, hegemonic 
notions of culture, has indeed turned into a bleak version of the Black Atlantic, and many critics have noted-and condemned-that "Benito Cereno" leaves no space for utopian possibility or "remedial action" (Levine 1989, 224), "no ... hope about the fruitful merging of cultures" (Sundquist 1986, 107). Unlike in Emmanuel Appadocca, emancipation and free selves are exposed as always already tainted by a history of institutionalized slavery that even the U.S.-American captain cannot escape (James 1953, 133-34). In "Benito Cereno," any notion of a New World utopia is rendered null and void, as "past, present, and future seemed one" (Franklin 1992). The novella brings together "the convulsive history of the entire region and epoch-from the Columbian discovery of the Americas, through the democratic revolutions in the United States, Haiti, and Latin America, to the contemporary crisis over the expansion of the 'Slave Power' in the United States" (Sundquist 1986, 94); beyond this, it yokes together Europe, Africa, the Atlantic, the Americas, and the Pacific Rim as all tainted by the institution of slavery. ${ }^{48}$

In this light, U.S.-American perceptions of itself as exceptional in, and pushing forward, world history, appear as self-complacent as they continued to repress the shadow of "the negro" while simultaneously emulating the hegemonic ambitions of European powers, hence entering the vicious circle of history (Schnackertz 1993, 179). This repressed shadow would return all the more vehemently with the Civil War, arguably the most fundamental crisis in terms of the union of the U.S. Republic; again, especially in the early war years, the figure of the pirate was articulated in conjunction with the debate over the legitimacy of both Southern Secession and slavery. On decorated envelopes, caricaturists envisaged and ridiculed Southern "pirates," marking a shift away in the representation of piracy from literature to visual culture, a development that would continue into the twentieth and twenty-first centuries.

\subsection{The Figure of the Pirate at the Onset of the Civil War}

\subsubsection{The (Il)Legitimacy of Secession}

The years leading up to, during, and following the Civil War were "years of intense anxiety, as many categories in the United States were in flux" as a result of the shattering of the slave system (De Grave 1995, 120) 
and of the influx of immigrants. Countless historians have talked about sectional conflict between North and South in terms of crisis: "Sectional Crisis" (Graebner 1977; Rosenberg 1971) or a Crisis of Republicanism (Ambrosius 1990), a "Crisis of Disunion" (Johannsen 1963) or Crisis of the Union (Knoles 1965), a "Constitutional Crisis" (Bestor 1964), a "Crisis of Congress" (DiNunzio 1972), even a Crisis of Fear (Channing 1970) or a "Crisis in Law and Order" (Paludan 1972). Among many others, Bowman, titling his study of the Civil War At the Precipice: Americans North and South during the Secession Crisis (2010), characterizes sectional conflict as indeed a precipice, an existential point of political life or death, for the United States and her Constitution, exploring contemporaneous Southern alongside Northern arguments for the legitimacy of their respective actions-declarations of Secession and war, respectively. Both sides, Bowman demonstrates, saw their course as legitimate in the sense of adhering to the principles of the founding documents of the United States. As early as 1856, Southern politicians claimed that the election of a Republican president, openly opposed to slavery, would provide a just cause for Secession, given that such a choice would mean a president unable to represent slave-holding states and economies (Bowman 2010, 2); in the North, both Presidents Buchanan and Lincoln denied the constitutionality of Secession (though Buchanan, unlike Lincoln, held that the Constitution gave him no power to force a seceded state back into the United States; 7). When the South violently refused to hand over Fort Sumter to the Confederacy in 1861, Lincoln ruled that this rebellion against U.S. authority was unconstitutional and exceeded juridical power, forcing the Union to declare war. Both North and South, Bowman continues, saw themselves as American patriots, however, preserving what they thought to be genuinely American institutions and values as custodians of the legacy of the American Revolution: "they thought to appropriate for themselves the contested legacy of true Americanism" (11) and glorified both the Declaration of Independence and the U.S. Constitution $\left(13,18,29\right.$; also McClintock 2008, 8). ${ }^{49}$ For the South,

[the] right of state secession and the liberty to form an independent Confederate States of America could be based on Confederates' interpretation of the old U.S. Constitution and the Union as created by sovereign states in 1787-88. The right to leave the Union could also be derived from the inherent liberty and freedom of ... republican citizens to rebel against 
some political authority they viewed as threatening despotism, tyranny, and metaphorical enslavement and therefore by definition oblivious to the inalienable natural rights described in the Declaration of Independence. (Bowman 2010, 14)

Thus, Jefferson Davis could identify "oppressive northern free states" with the tyranny of England in the 1770s (29). Even when he was still a senator, Davis "maintained that the states had the power to secede from the Union whenever-in the judgment of a state- the need to protect the rights of its citizens necessitated withdrawal" (Boyd 2010, 28), and hence most Southerners believed that the North was responsible for the war following "the Confederacy's legitimate act of secession" (29).

Northern discourse at the beginning of the 1860s, by contrast, portrayed the enslavement of blacks in the South as an evil and felt firmly that a slave state had neither cause nor "constitutional warrant to sever its ties to the United States simply because a man of antislavery principles had won the presidency"; indeed, "[t]he efforts of the South's leadership to create ... a separate nation constituted criminal acts of treason and piracy" (Boyd 2010, 23):

All men loyal to the glorious legacy and vision of the Founding Fathers should join hands against arrogant and treasonous rebels who seemed hellbent on crippling and dishonoring history's greatest example of republican self-government. Secessionist slaveocrats were willing to sacrifice the noble experiment in liberty embodied in the United States of America simply because they wished to perpetuate a distinct, distasteful, and anachronistic regional interest, black chattel slavery. (17)

This view led to Northern demonizations of the South and its alleged alliance with the devil, and explains "why such intense antipathy was directed toward the South's political leadership" (Boyd 2010, 23), especially Jefferson Davis, from the very outset of the War. However, it is noteworthy in the context of this chapter that strong racial prejudice existed both among northern Unionists and southern Confederates; apart from a few radical abolitionists, most Americans did not envision African Americans, whether free or slave, as entitled to liberty or equality before the law and in social matters (Bowman 2010, 12, 20). 


\subsubsection{The "Pivacy" Cases of 1860/1861}

The Secession crisis as such can be dated from December 1860 to April 1861 (Stampp 1945; Fahs 2001, 44). On December 20, South Carolina declared that it would leave the Union: the consequences of Secession were unclear and its constitutionality and legitimacy hotly debated in public, from the newspaper to the courtroom. The Confederate attack on Fort Sumter on April 12, 1861, led to Lincoln's declaration of war, and in June, Mississippi, Florida, Alabama, Georgia, Louisiana, Texas, Virginia, Arkansas, North Carolina, and Tennessee seceded.

Jefferson Davis called for privateers, issuing letters of marque to Southern ship captains as a response to Lincoln's declaration of war on April 17, 1861, for lack of a C.S.A. navy: "Faced with a federal blockagewhich Southerners considered illegal-and an impending shortage of imported foodstuffs and war materials, Davis felt he was obliged and had the right to authorize such raids" (Boyd 2010, 48). While Northern abolitionists like William Lloyd Garrison had themselves called for Secession from the slave-holding South, the Southern Secession movement was now met with bewilderment: "Given the centrality of the principle of law and order it stood to reason that no matter how one felt about the legitimacy of Southern grievances or the need for Northern concessions, secession-especially when accompanied by the seizure of federal property-represented a shocking violation of the law .... The notion that secession was a legitimate right was 'absurd' not just to Republicans but to most Northerners" (McClintock 2008, 144). Although the United States had not signed the 1856 Treaty of Paris, which prohibited privateering in international law, the Northern response to Davis's call used the rhetoric of piracy in order to delegitimize Confederate privateering, which had "incensed Northern citizens and Union officials alike, who insisted that since the Confederacy was not a sovereign nation, the actions of Confederate sea captains constituted piracy" (Boyd 2010, 48) and were criminal: Lincoln's "Proclamation 81-Declaring a Blockade of Ports in Rebellious States" of April 19 spoke of "pretended letters of marque" and "disorderly proceedings" used against "good citizens of the country lawfully engaged in commerce on the high seas and in waters of the United States" (Lincoln 1861, n.p.); in order to protect "the lives and property of quiet and orderly citizens," Lincoln issued the blockade of Southern seaports and declared "that if any person, under the pretended authority of the said States or under any other pretense, shall molest a 
vessel of the United States or the persons or cargo on board of her, such person will be held amenable to the laws of the United States for the prevention and punishment of piracy" (my emphasis). Insisting that the seceded states had no right to political authority and that any performance of authority (such as the issue of letters of marque) could thus only be "pretended," Southern privateering was redefined as piracy despite U.S. acceptance of privateering as such. Newspapers jumped on the bandwagon, running headlines such as "President of the Cotton Confederacy Stimulating Piracy" (Liberator, April 26, 1861) or "Encouragement for Pirates" (New York Times, May 11, 1861).

However, Congress did not bestow formal legitimacy on a naval blockade of Confederate ports until July 13, and hence Lincoln's unilateral imposition faced legal challenges. The question was whether ships that had violated the blockade prior to the Congressional endorsement were captured lawfully; it was finally settled by the Supreme Court in the 1863 Prize Cases, which concurred that both the blockade and the seizures were defensible only if a state of war existed. The judges did not agree on the question of the president's authority to take war measures without a congressional declaration, but finally approved Lincoln's declaration retroactively by a 5-4 majority (Bowman 2010, 284; Weitz 2005, $5)$.

The issue that had to be considered in all subsequent trials for piracy was whether the conflict could be considered, in legal terms, as war, revolution based on natural rights, or merely internal rebellion. In late 1861, three landmark cases, in which Confederate sailors of the Petrel, the C.S.S. Savannah, and the Jeff Davis caught raiding Union vessels were tried for the capital crime of piracy, put this question to the test and also revealed conflicting Union positions as they saw contradictory outcomes: while the Petrel and the Savannah crews were not condemned because of a deadlocked jury, the Davis privateers were hanged. As Mark Weitz reveals in his elucidating monograph The Confederacy on Trial: The Piracy and Sequestration Cases of 1861 (2005), these were instrumental in debating and ultimately shaping the Confederacy's identity and legitimacy. Closely examining trial and newspaper reports, Weitz shows that their defense argued that they were not pirates at all but privateers acting on behalf of a sovereign nation. Thus, they were entitled to protection under international law as prisoners of war (and hence could not be executed) - a notion the prosecution combatted vehemently: 
To acknowledge Confederate seamen as privateers might legitimize the letters of marques issued by Jefferson Davis, under whose authority they sailed and made war. To do so would validate the acts of the Confederate legislative and executive branches. It not only would elevate these men to the status of combatants but also might well define the Confederacy as a nation, if not de jure, at least de facto, and in the process pave the way for foreign recognition. (7)

Addressing the difficulty of discerning whether a conflict is a rebellion or a war between nations as long as it remains undecided, Weitz not only argues that the Confederacy struggled to balance civil rights and state sovereignty with the need to wage war, but also that the Union walked a fine line between officially sanctioning the Confederacy and utilizing war powers normally directed at enemy nations. In any case, Davis's call for privateers was a shot across the bows: not only did some of those that followed it attack ships indiscriminately of national colors; most C.S.A. privateers were also caught and tried for piracy in U.S. courts. ${ }^{50}$ In addition, Lincoln's declaration of piracy also referenced a popular cultural topos that newspapers, writers, composers, and lithographers were happy to take up in support of the Union.

\subsubsection{Piracy on Union Envelopes}

Critics such as Alice Fahs, Cameron Nickels, or Shirley Samuels demonstrate that the Civil War was also a war of images and imaginations. Civil War print culture, both through word and image, created "fictive affective bonds" (Fahs 2001, 9), bonds which precondition collective identification and an imaginary of differences between North and South. Image designers and printers "created an iconography ... that both reflected and shaped the cultural and political meanings of the war for the people" in a "dynamic process" (Nickels 2010, xi). In this sense, illustrated envelopes, or "covers," as they are also known, ${ }^{51}$ constituted a popular cultural attempt at securing the allegiance of civilians on the symbolic battlefield of paper-hence Nickels speaks of a "Paper War" (1) that was essential to Americans' reactions to the actual war. ${ }^{52}$

The specific medium of illustrated postal envelopes, one of the many new genres in nineteenth-century visual culture, was employed since the 1840s, when political parties had used decorated envelopes in their rallies, trying to appropriate traditional U.S.-American symbols such as the eagle, 
Columbia, or George Washington for their own ends; also, business stationery started to make use of the blank space of envelopes for advertising purposes, and reform movements such as teetotalers or abolitionists realized the power of images in order to trigger and direct particular emotional responses (Berry 2005, 12-13). With the start of the Civil War, stationery companies and lithographers tried to "link themselves to, and profit from, patriotism" (13). In addition, at least in the major cities of the North, the war had furthered the modernization of inexpensive print as a mass medium, and advances in lithography and printing had produced many forms of print that were now cheaper-and more patriotic - than ever: broadsides, song sheets (also called 'penny ballads'), trading cards, and pictorial envelopes (Nickels 2010, 3). Drawing on these developments, lithography thrived during the Civil War. The early 1860s saw an explosion of richly illustrated envelopes, unparalleled in "scale, scope, and sophistication" in the history of American printing, as Stephen Berry states $(2005,13)$, and were pivotal for later developments in stationery such as the postcard. The craze for pictorial envelopes made them collectibles early on (Fahs 2001, 43), but they were of course also used, by civilians and soldiers alike. The massive amount of correspondence between armies and home front resulted in their wide dissemination, even "ubiquitous presence" (Gallagher 2011, 58). Pictures on envelopes, according to Josephine Cobb, could also be produced more rapidly than other kinds of pictorial illustrations: they required less skill and less expensive equipment, with metal stock cuts being borrowed or purchased from type foundries and printed on small hand presses such as the Adams Cottage Press, which promised to make "Every Man His Own Printer" (Cobb 1963/1965, 234). Not all envelopes, however, carried imprints; in the case of political caricature, the designs were meant to remain anonymous. At other times, the lack of imprint could imply a pirated version of existing designs (236).

Decorated covers were especially popular in the early days of war, when patriotic fervor was at its peak. About three hundred printerpublishers (such as the Gibson Brothers, Henry Polkinhorn, or Samuel Siebert in D.C.) produced thousands of different designs, sold by booksellers and shops across the nation, North and South. Lincoln's blockade, however, leading to shortages in paper, ink, and stoneware for lithography (among others), was a large factor responsible for the Confederate defeat in what Berry has called the "Lithographers' War" (2005, 12; 
also Cobb 1963/1965, 234 n. 4). Compared to the Union's, Confederate patriotic covers were hence much less numerous, most of them having been issued in 1861 and 1862. They focused on Confederate national icons such as the flag and the President (Boyd 2010, 27), but as a counter-discourse to Northern patriotism, they, like the North, also tried to recur to existing national icons to claim legitimacy for Secession. Thus the South was met with "symbolic' challenges" (13) in trying to create a distinct iconography of their own: the palm tree was not as strong as the Massachusetts pine, and the "Don't Tread on Me"-snake bore unfortunate biblical connotations (13-14); images of Jefferson Davis were safest in this respect, joining - and to a degree displacing, at the outset of the war-those of George Washington throughout the South, as the Confederate leader became, along with the Confederate flag, the key symbol of the new 'nation' and its government (Boyd 2010, 52).

Northern printers had the advantage of being able to use countless established symbols for the Union such as flags and allegorical figures like Columbia and the American eagle, the Union shield, and famous U.S. leaders. In addition, they satirized Southern symbols and delegitimized Secession symbolically by infantilizing and ridiculing the C.S.A. Combining image and text to "remind citizens about the value of a war for Union" (Gallagher 2011, 57)-for a democratic Republic, for the Constitution, for the founding generation-they often made the extra-legality of Secession a main theme. The symbols used were stock ingredients to represent the Union, the Constitution, and the rule of law in order to deny the South the legitimacy of a sovereign state, while connections to the devil marked representations of the South. "This linkage with the Devil also explains ... the certainty with which Northern printers could condemn Jefferson Davis with no presumption of innocence or right to due process of law" as Northerners "presumed that their cause was a divinely inspired campaign to carry out the will of God by exterminating the minion of the Devil, Jefferson Davis" (Boyd 2010, 25). Thus

$[t]$ he Union patriotic envelopes illustrate key aspects of the crisis from the point of view of the North. They show how secession posed a material challenge to the existence of the nation, how printers in the North developed various depictions and symbols to rally citizens in support of their view of the war, and ... fostered the demonizing of President Jefferson Davis and the South. (27) 
Many of these pervasive symbols explicitly reference piracy: pirate flags and the iconography of pirate figures (see below), together with the aforementioned association with the devil, were key in the demonizing of Davis and the South. At other times, it was the mention of the term alone that sufficed to make the claim of Southern illegitimacy, for example in Fig. 4.1, both calling for the death of Southern "pirates" "to secure our Ports."

These are rare examples in which the accusation of piracy is envisioned in a serious tone rather than in the mode of caricature. Notably, they are also exceptional in using female figures in this context: Fig. 4.1 portrays a couple defending the Union, with the male figure (appearing with a Lincoln-esque beard) on the lookout for pirates and carrying the flag almost as if it were a weapon of defense, while the female figure, in a much more passive position leaning on the man's legs for protection, seems to guard the maritime wealth of the Union. In Fig. 4.1, an allegorical female Neptune-like figure resembling a swarthy Britannia, also sitting, takes the role of the man in Fig. 4.1: on the lookout for the enemy pirates (the caption suggests she is guarding a port), her gaze seems fierce and concentrated, ready to use her trident in defense.

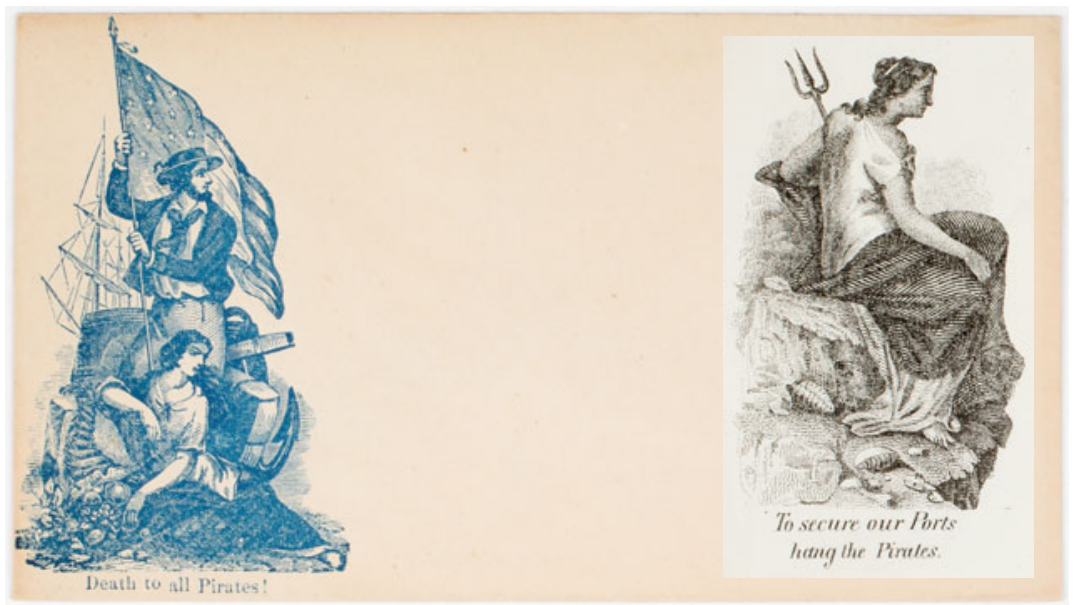

Fig. 4.1 Two prints on Union envelopes asking for the death of Southern "Pirates" (Figures courtesy of the American Antiquarian Society) 
An example of a primarily verbal evocation of piracy on Union envelopes is the modified Confederate eight-star flag, bearing the names of the South's president and vice president but adding "The Pirate Flag" to the blue, "thereby implying that any vessel that flew the Confederate flag was committing piracy" (Boyd 2010, 48; see Fig. 4.2) and that the Confederate flag was in truth a disguise for the skull and crossbones; in his interpretation in the only existing monograph on patriotic envelopes of the Civil War, Steven Boyd states that "Davis's marque was not that of a sovereign nation at war with the United States but that of the Jolly Roger," an accusation that "resonated with people of the North" (48) who saw Davis's letters of marque as illegal. The real Secession flag, according to most Northerners, would show the skull and crossbones. The use of flags on decorative envelopes was all the more important because they were symbols of honor, pride, and legitimacy; the parody used a popular sign of illegitimacy in order to propagate the Northern cause, which explains the pervasiveness of the Jolly Roger on Union covers, as in Fig. 4.5 (see below), inscribed simply with Davis's initials and the words "J. D. His Marque" often added to remind people that

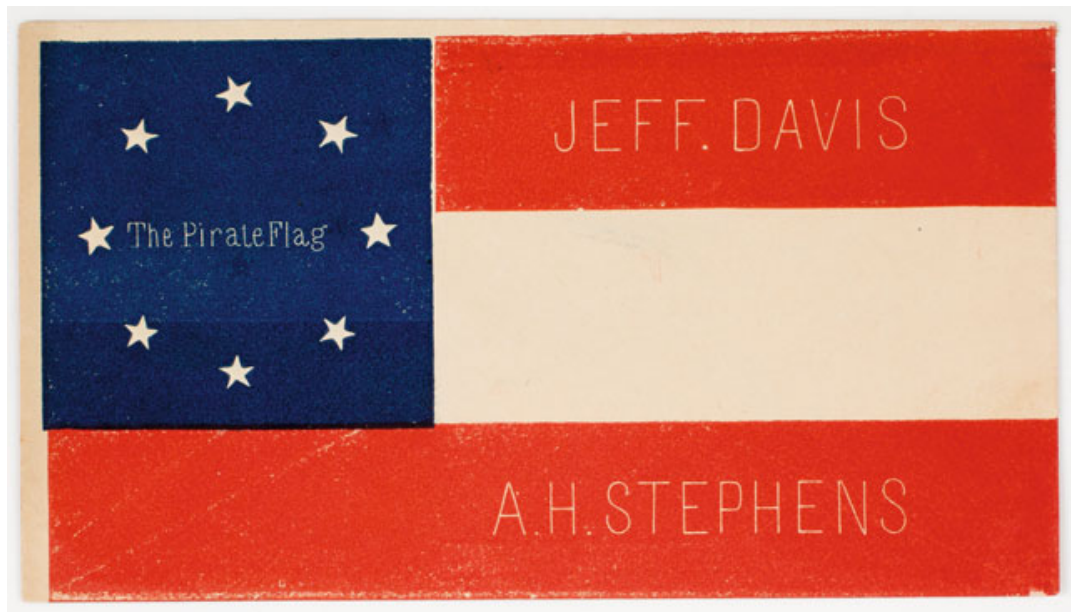

Fig. 4.2 Union envelope covered in its entirely by "The Pirate Flag," representing eight seceded states through eight stars and referencing President "Jeff. Davis" and Vice President A. (Alexander) H. (Hamilton) Stephens (Courtesy of American Antiquarian Society) 
Davis's authority to issue letters of marque was as illegitimate as that of a pirate. In Fig. 4.3, "J.D."'s "marque" is symbolically defeated by the "Marks" of "A[braham] L[incoln]," referring to the holes shot into the Jolly Roger flag and flag pole.

A different example (Fig. 4.4) also directly references issuing of "Letters of Marque and Reprisal" by the Confederate government in 1861 and ridicules Davis's letters of marque by spelling out six letters of "mark": "PIRATE."

Here, Davis confronts his own menacing "pirate" shadow (the "Letters of Mark" seems to be a popular misspelling of the "Letters of Marque"). On Union envelopes, Davis is usually subject to caricature, "most often being hanged, mocked, or otherwise reviled" and so "turned up frequently as the prime traitor to undo the Union"; one image of this sort shows him on the gallows, the caption reading "Jeff. Davis, 'President' of Traitors, Robbers, and Pirates; the Nero of the 19th century" (Gallagher 2011, 57). The mangling of Davis's image-the personification of the Southern Confederacy-into that of a pirate, juxtaposed with Lincoln's sacralized counterfeit, personalized the impending war (Boyd

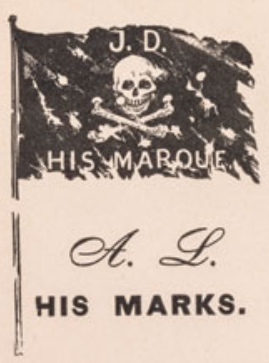

Fig. 4.3 Bearing a tattered skull-and-crossbone flag pointing to the doom of the seceded states, this envelope adds "A. L. His Marks" to draw a color contrast between the 'dark' forces of the South and Abraham Lincoln's stainlessness (Courtesy of American Antiquarian Society) 


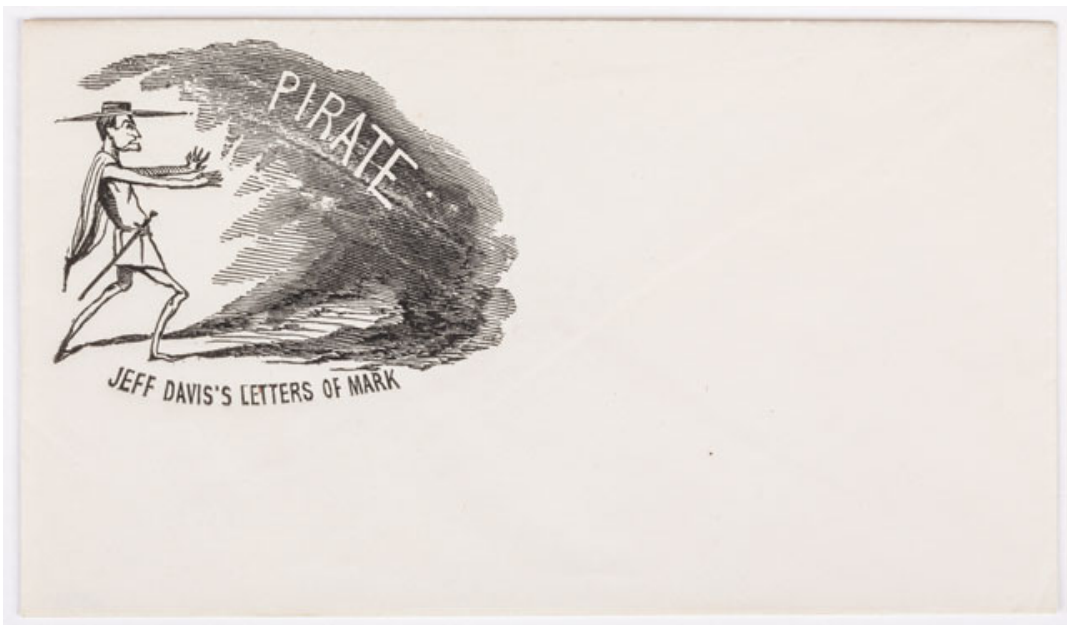

Fig. 4.4 A caricature decorating a Union envelope on the left hand corner, portraying Jefferson Davis as barely keeping at bay the pirates he created (Courtesy of American Antiquarian Society)

2010 , ch. 3). The disparagement of Davis and the Confederacy proved persistent, but, ironically, they also helped make Davis better-known in the North than before the War (64-65). Examples of caricatures include Davis as a mangled "shanghae" (a Chinese fowl) chicken on a March toward Washington (Fig. 4.5), which, however, is guarded by a proud and strong "Union Game Cock." If read sequentially, they even suggest that the Union rooster, whose body and star-spangled banner are much larger, the latter shining colorfully due to three-dimensional visual effects, has succeeded: "J.D." and his amateur black flag recede, ridiculed by the question "Jeff, when will you get here?" uttered by "W.S." (perhaps referring to General William Sherman, whose early battles, ironically, were not successful).

Davis also takes on other animal forms, for example that of a spider with the head of Jefferson Davis, marked by the skull and crossbones (Fig. 4.6) and luring ever more flies (i.e., States) into his "Secession Web."

The flies are labeled with state initials including those of Mississippi, Arkansas, Texas, Louisiana, Alabama, Florida, and Virginia; flies labeled Maryland and Missouri are approaching the spider's web, which, notably, is attached to a Union flag. The suggestion is that "neither Missouri nor 

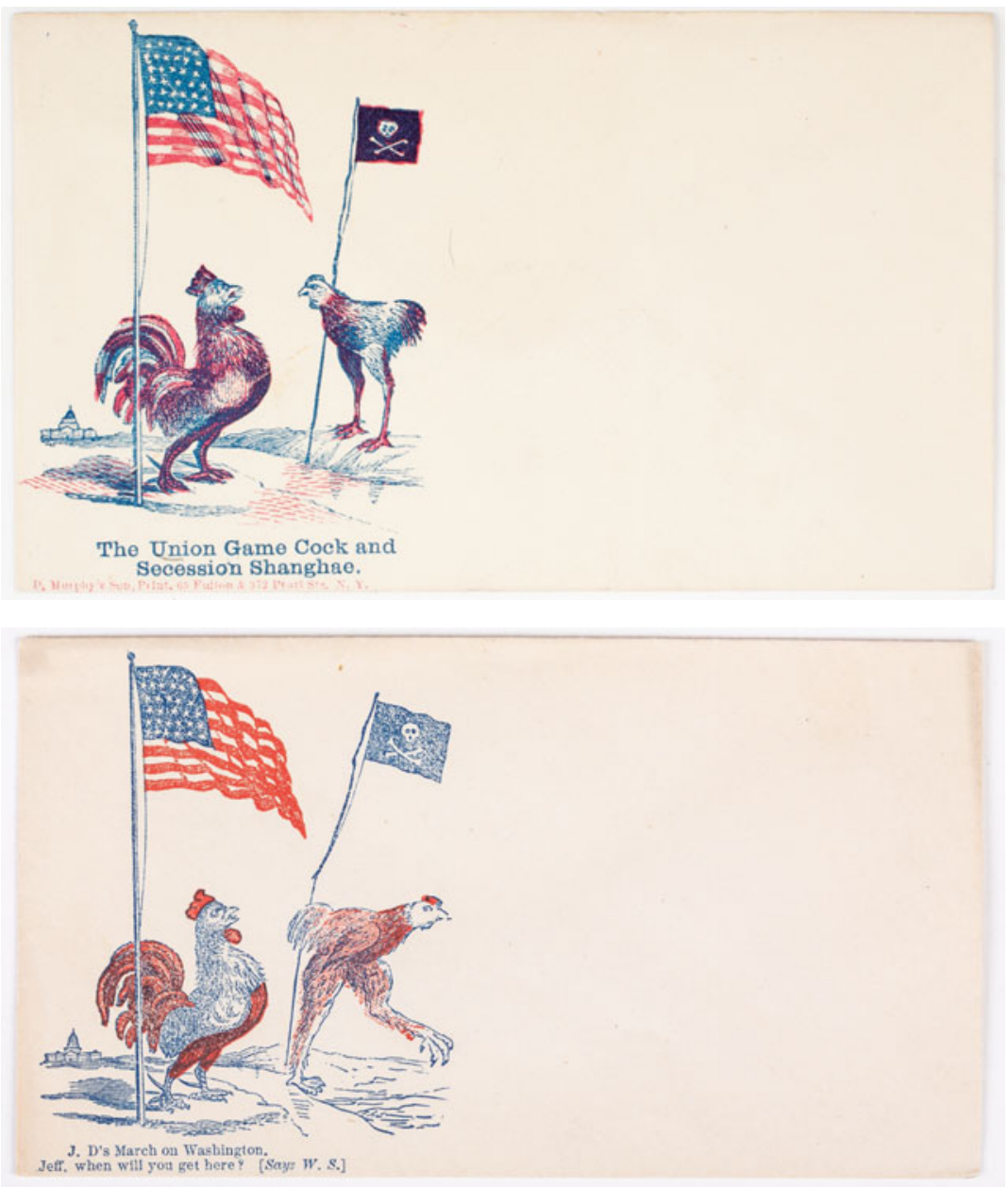

Fig. 4.5 Union envelopes with satirical cartoons, probably published as a series and hence anticipating the comic strip. These two tell a narrative in which a proud "Union Game Cock" confronts a piratical "Secession Shanghae" on his "March on Washington," ridiculing "Jeff"'s inadequacy to "get here" (Courtesy of American Antiquarian Society) 


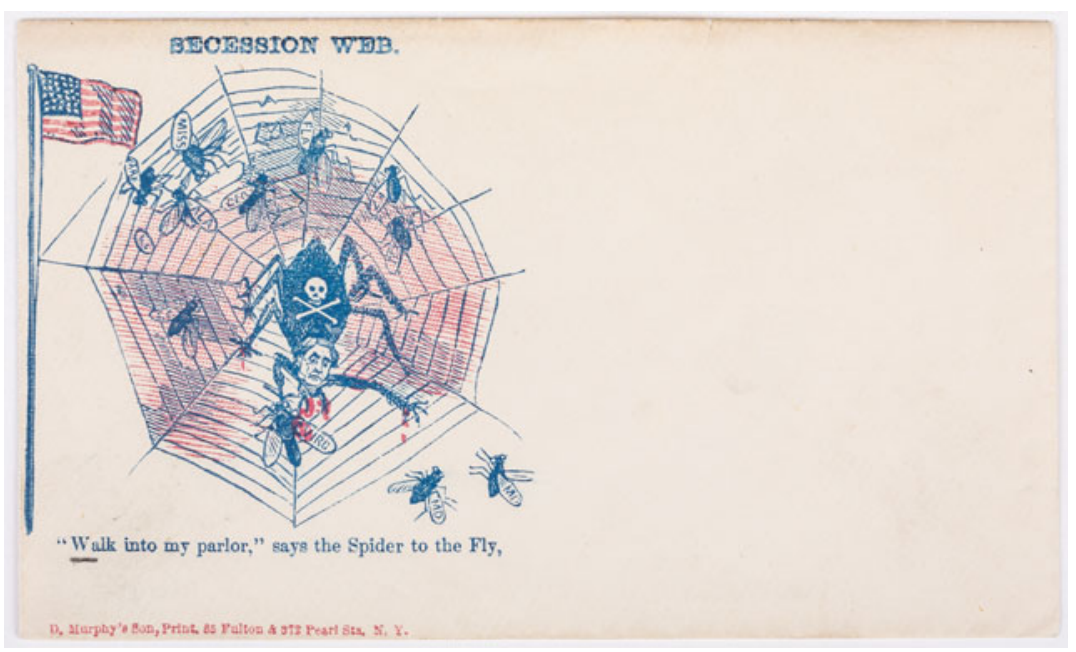

Fig. 4.6 Satirical cartoon decorating a Union envelope with a "Secession Web" and a piratical spider, asking the flies (representative of single states) to "[w]alk into my parlor" and thus to certain death (Courtesy of American Antiquarian Society)

Maryland will sacrifice the liberty secured by the Union to join the secession trap set by the pirate Davis" (Boyd 2010, 64), but also that Davis and the project of Southern Secession is as threatening to the Union as a spider on a pole. In this context, Shirley Samuels notices the abundance of pejoratively used human-animal mutations in a study of Civil War iconography, interpreting it not simply as a strategy of ridicule but also as expressing anxieties about racial and national identification provoked by the Secession crisis, anxieties which became displaced onto matters of gender and human-animal distinctions:

these dislodged identities take the most anxious fears and desires of nationalism and produce through them truncated accounts of how identity can or cannot adhere to the public space opened by national conflict ... if male can become female, white can become black, and human become animal-awkward parallels suggested by the crude caricatures of wartime America-then what nation is left for the citizen to inhabit? (29-30) 
Similarly crude caricatures of Davis include designs for his "Coat of Arms," changed into a coat of "Alms" (in reference to the perceived material inferiority of the South that unsuccessfully tried to secure financial assistance from France and Great Britain for warfare), designs that centrally display the skull and crossbones, which is encircled by the seductive yet treacherous rattlesnake of Secession: added is a bottle of moonshine whiskey, evoking stereotypes of Southern alcoholism (including Davis's own escapades) and associating them with drunken pirates, and the motto "Oh! Let Me Alone!" at the top of the shield.

After Lincoln's condemnation of Southern piracy, the Confederate privateering 'navy' became another object of ridicule, as "Union covers portrayed bedraggled and booting pirates adrift in leaky vessels with tattered flags" (Berry 2005, 14). In Fig. 4.7, a Confederate captain (presumably devised as an embodiment of Davis) and six Confederate sailors float in a bowl flying a Jolly Roger, on an eager watch-out for the enemy. The image suggests both Southern naval-military inferiority and the naïve belief that the C.S.A. could win a sea-battle against the Union. It also marks Southern naval-military strategies as piratical: instead of an official navy, "Jeff's" is a "Knave-y" made up by "wise men of Gotham" (referencing Washington Irving's 1807 Salmagundi Papers, which were

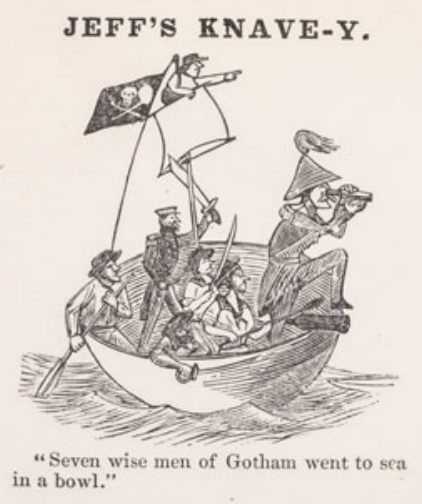

Fig. 4.7 Union envelope decorated with a caricature of the Southern "Knave-y" (Courtesy of American Antiquarian Society) 
based on the Merrie Tales of the Mad Men of Gotham, a 1460 collection of legendary stories of foolish, rather than wise, villagers of Gotham, Nottinghamshire).

In contrast, another cover (designed by John G. Wells [1821-1880]) shows the U.S. Navy is envisioned as an enormous "American Eagle coming down on the C. S. A. pirates," thus its caption, with a huge eagle claw coming down from the sky above several Confederate ships from which people are leaping into the water to escape. Northern superiority and legitimacy are likewise at issue in similar example, printed by D. Murphy's Son of New York, in which an armed Union sailor watches a man in pirate boots (marked with skull and crossbones) as he falls through a hole in a ship's deck during battle, with the caption reading "Union Jack sending one of Jeff Davis' pirates to 'Davy Jones locker'-Serves "em right."

Another example, also printed by Murphy, is less general and directly alludes to political events: in Fig. 4.8, Queen Victoria ("Victoria Rex," a grammatical mistake as it should be "Regina," embodying England with her Union Jack shield) sits on a lion who almost seems to laugh at a striding rooster below, exhorting the Queen with a Confederate flag

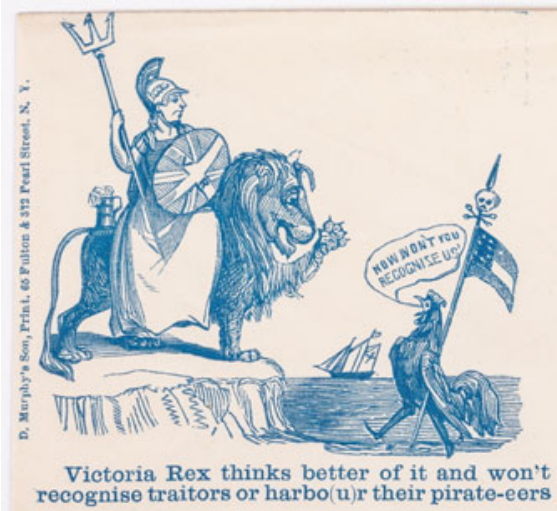

Fig. 4.8 The international dimension of the conflict and the C.S.A.'s plea for recognition by England is referenced in this decoration envelope (Courtesy of American Antiquarian Society) 
and skull-and-crossbone figurine on top of the flagpole: "Now won't you recognise us!" But, the caption tells us, the Queen "thinks better of it and won't recognize traitors or harbo(u)r their pirate-eers." Linguistically diluting the term "privateers" into "pira-teers" and referencing the fact that Great Britain refused Southern pleas for recognition, the caricature delegitimizes Southern self-descriptions while, at the same time, pictorially suggesting that Britain sided with the Union in the war against the Confederacy.

Yet another subset of caricature patriotic Union envelopes ridicules Southern capabilities of naval-military action not through the use of animals but by strategies of infantilization, such as in Fig. 4.9, titled "A 'Horse Marine' of the C.S.A.," in which a plump figure of childlike proportions, wearing a naval hat adorned with skull and crossbones, sits atop a wooden children's horse (whose tail is replaced by a C.S.A. flag) with a spyglass in his hand. By the mid-nineteenth century, pirates began to turn into prominent stock characters in children's literature on both sides of the Atlantic, as adventure literature for boys was the craze of the time. This caricature also has to be seen in context with numerous others in which Jefferson Davis's attempt at establishing the Confederate States

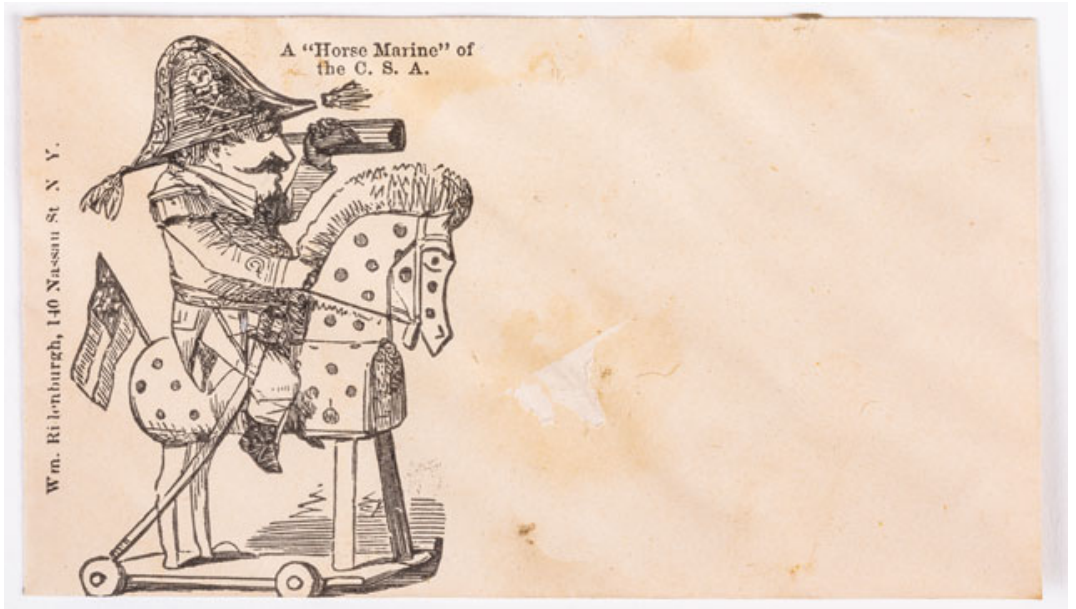

Fig. 4.9 Ridiculing Southern naval capabilities: a "Horse Marine" of the Confederate States adorning a Union envelope (Courtesy of American Antiquarian Society) 
of America was mocked as the delusive fantasy of an immature, quixotic boy who had read too many adventure novels rather than as a political project one could take seriously. As the war progressed and thousands of soldiers, Northern and Southern, left their lives in the battlefields, this infantilizing strategy was abandoned; it would have been cynical indeed to continue this mockery in the face of death.

Deriding Confederate naval warfare, Union envelopes also popularized specific cases of Southern defeat on the seas in order to strengthen a feeling of Northern superiority that was in no real danger vis-à-vis the dilettantism of Davis's privateers. One cover, for instance, caricatures Captain Baker of the C.S.S. Savannah, again using childlike proportions (a large head and small body). The caption is another ridicule: "Capt. Baker of the pirate 'Savannah,' is astounded to find that the vessel he is trying to overhaul is the man-of-war brig Perry."

\subsubsection{The Iconography of Slavery and Piracy}

The Civil War use of the trope of piracy, at least to some extent, also takes up the Black Atlantic critique of slavery as piracy. The conjuncture was used in popular anti-Southern discourses during the war as envelopes depicted Jefferson Davis and the seceded South as pirates, robbing Union ships, exploiting African-American slaves, and betraying the United States by means of a Secession thus delegitimized. The Southern Secessionist 'pirate' was not just a figure who plundered Union ships; by their occasional representation of the peculiar institution, Northern patriotic envelopes also evoked the association of enslavement as the 'pirating' of human beings. Thus, the iconography of the decorated envelopes took up the semantic association of piracy and slavery introduced in late eighteenth-century enlightenment discourses and continued in Black Atlantic writing. Union envelopes sometimes "utilized images of African Americans to satirize the citizens and soldiers of the South, their goals and social order, and their claims of slave contentedness ... to encourage Union soldiers and civilians to persevere in the battle against a debased, morally bankrupt, and soon-to-be defeated South" (Boyd 2010, 71).

Examples like Fig. 4.10-two oval images enclosed within a rope, the top one showing a proud Davis in military uniform and the bottom one having him dig potatoes in the hot (but smiling, perhaps mockingly) sun, barely clothed and sweating, with a fully clad freedman holding a cat-o'-nine-tails, - draw on the South's biggest fear, that of a reversal 


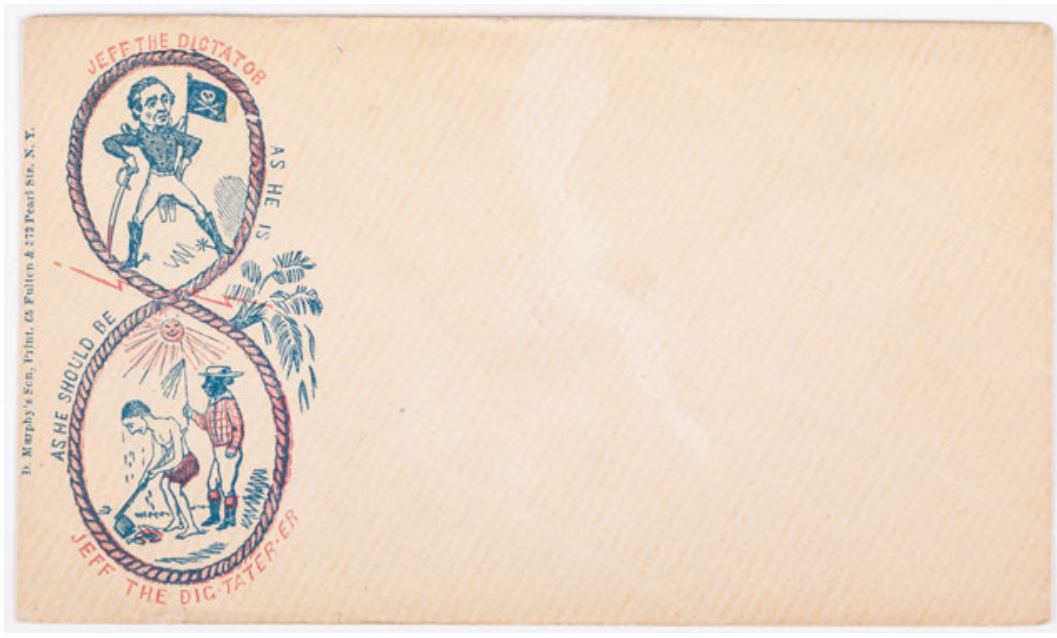

Fig. 4.10 "Jeff the Dictator as He Is" and "Jeff the Dig-Tater-er As He Should Be." Decorated Union envelope interrelating slavery and piracy (Courtesy of American Antiquarian Society)

of power structures between black and white, and of black domination of former 'piratical' slave-holders. Transforming the Southern "dictator as he is" into a "Dig-tater-er as he should be," this envelope satirically projects a reversal of status "not envisioned by even the most radical of Republicans during the war" (Boyd 2010, 75) and hence denies Southern assertions of the "contented and happy slave" (Fahs 2001, 151). In addition, this example can be read as somewhat of a regionalized expression of black revenge on the Southern 'piracy' of humans-rather than an endorsement of African American mastery across the Union. Also, few of these were postally used, which suggests, in Boyd's view, that Northerners, too, were reluctant to publicly embrace an antislavery message in $1861(2010,77)$ but enjoyed any kind of satire of the South. Depictions of slaves, Boyd asserts, were in the majority regarding (in any case rare) prewar visual representations of African Americans, both North and South (68). Before the war, popular visual culture often showed slaves at ease in Dixie and almost always bordered on dehumanizing caricatures of human beings - with stereotyped physical characteristics, dress, and dialect; more often, they had no face, no visual representation at all 
(69). While Union envelopes changed the latter, it is no surprise that many nevertheless perpetuated stereotypes of passive African Americans with accentuated characteristics (71; also Berry 2005, 16; Gallagher 2011, 57)-though there were exceptions: Fig. 4.11 suggests the abolition of slavery as the goal of the war; in other instances, enslaved blacks' active role in their liberation as well as their contributions to the war effort are highlighted, assertiveness replacing subordination. As Fahs contends, illustrated envelopes explored the emerging story of black freedom during the war, joining the contemporaneous fascination with black action in popular literature $(2001,13)$. Northern envelopes

embraced changes in African Americans' status during the war-although usually only if they seemed to benefit the condition of Northern whites ... . Redefining former slaves as 'contrabands,' then portraying them as minstrels, was in part a strategy of containment. It reassured white Northerners that even in freedom African Americans remained no more than property and that familiar images from minstrelsy retained their currency in wartime as a mode of imagining blacks. Such linguistic and visual strategies

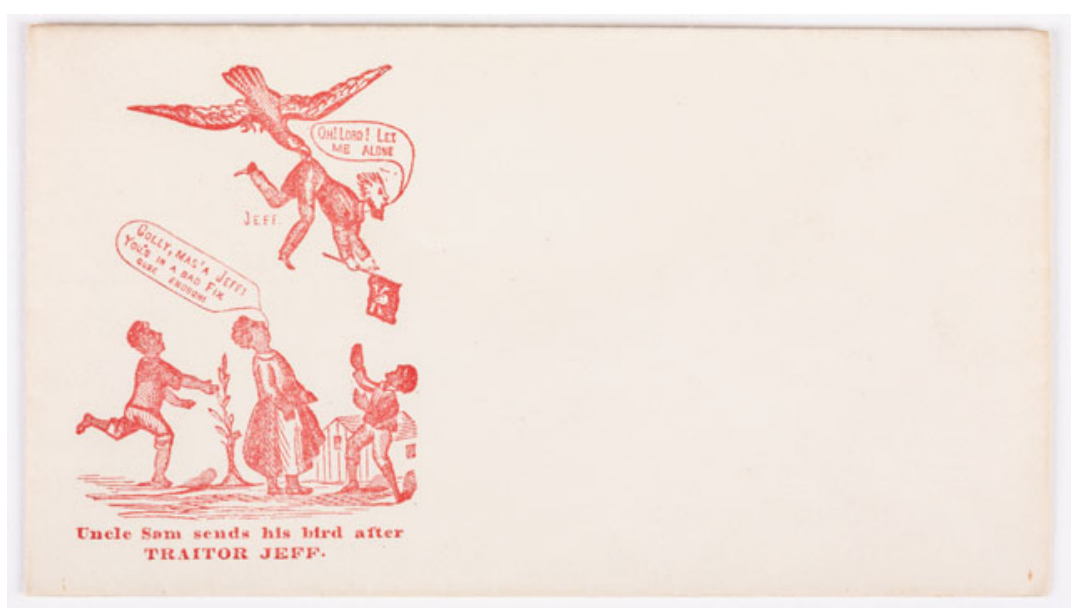

Fig. 4.11 Decorated Union envelope; "TRAITOR JEFF" Davis, pirate flag in hand, is abducted by Uncle Sam's Eagle, putting a family of plantation slaves in commotion. Notably, it is the female slave who comments on "Mas'a Jeff's" "bad fix" (Courtesy of American Antiquarian Society) 
in effect forestalled thinking of African Americans as free human beings. (151-53)

Simply labeling these caricatures unflattering, as The Catalog of Union Civil War Patriotic Covers does (Weiss), hence misses that they were intended as satirical criticism of the South rather than as caricatures of blacks, and generalizes all covers with black images into one category, as Boyd has criticized $(2010,73)$. Certainly, African American emancipation might not have been a major subject for these covers (Gallagher $2011,57),{ }^{53}$ some of which even expressed Democratic unhappiness with emancipation or drew on images of minstrelsy. As in the examples above, however, we can also read Northern patriotic covers as anticipating and to some extent helping prepare the ground for Lincoln's Emancipation Proclamation of 1864, creating a visual alliance between the North and the Southern slave by displaying and mocking their common enemy. Envelopes depicting escaped slaves and designating them as contraband, for instance, "represented a challenge to slaveholders' authority that many Northerners clearly relished" (Fahs 2001, 151). Boyd concludes that envelopes with images of African Americans and an antislavery theme "constitute the first veiled suggestions that the 'War for the Union' might also become a war for the destruction of slavery" $(2010,76)$, though he admits that the preceding example is perhaps an exception, as most envelopes portraying blacks might have been perceived as "satirical hyperbole" and exaggeration rather than political critique (Berry 2005). He reminds us that before the war, "[s]laves depicted in the popular press and culture, North or South, accepted their dependence on a gentle, beneficial white society. Only a few abolitionist representations challenged this idyllic notion with portrayals of slaves brutalized by slavery and crying out for assistance" - a status quo that slowly began to change only with the onset of the Civil War. The end of the War, notably, also marked a break in the semantic conjunction between slavery and piracy; in the last decades of the nineteenth century, pirate narratives and visuals were re-romanticized and heroized in their turn to a very different readership: children. Many decades later, in the twentieth century and especially with the pirate's Disneyfication, were caricatures of pirates taken up-in less serious contexts-yet again. 


\section{Notes}

1. Julian Boyd remarks that of the sixteen charges in the so-called Composition Draft, this gets the most embellishment by the time it appears in the document Jefferson called his "original rough draft" $(1999,2)$.

2. The Barbary crisis has also been labeled repeatedly as the United States' first hostage crises or the "Tripolitan crisis" (Baepler 1999, 9).

3 . The tributary system that led to the practice of taking captives for ransom had originated during the Crusades and evolved in a Mediterranean economic and political system in the twelfth century (Rojas 2003, 164).

4. This summary overview of the U.S.-Barbary conflict draws on Tinniswood (2010, 280-95).

5. Lambert reports that it was "particularly galling to Americans that European powers legitimized the piratical states and paid them tribute when they could have easily destroyed them" $(2005,108)$; Portugal's truce with Algiers in 1793, for example, was seen as responsible for extending the range of Algiers and its pirates to American commerce across the Atlantic. He also notes that religious difference eventually lost out over economic difference in the U.S.-American construction of the Barbary 'pirate' (118).

6. Interestingly, American newspaper editor and author of a popular history of Algiers, Mathew Carey, concurred with this judgment in an antiSpanish rant (quoted in Lambert 2005, 111), but of course did not associate U.S.-American behavior in the international sphere with that of the Spanish conquerors.

7. See also the first part of Defoe's Robinson Crusoe. On the Barbary captivity narrative in Early Modern England, see Vitkus (2001); on the Barbary chapter in Miguel de Cervantes' Don Quixote and Voltaire's Candide, see Baepler $(1999,44-45 ; 2004,228)$; on the genre's European and American development, see Sutton (2009).

8. On seventeenth-century relations between European powers and the Barbary states, see Tinniswood (2010).

9. For a collection of pirate captivity narratives, see Stephens (1996).

10. On similar constructions of Arabs and Native Americans in Barbary narratives of Early America, see also Lambert $(2005,105)$, Berman (2007, $5-6)$, and Sutton (2009, n.p.).

11. In a sermon to commemorate the redemption of several Barbary captives in 1703, Cotton Mather had already called the North African corsairs "Hellish Pirates"; in a pastoral letter, he called them "Monsters of Africa" (quoted in Baepler 2004, 219; also 1999, 13). On Mather's stance toward Barbary, see also Hanna $(2015,205-206)$.

12. On the genderedness of the distinction between male-authored, 'authentic' Barbary narratives and women's fictional tales as well as of the genre's 
rhetoric of freedom, see Baepler (1999, 11-12, 16). On the popular "Algerian plays," see Montgomery (1994).

13. The canto echoes John Foss's report in his captivity narrative of a Christmas song the hostages of his ship sang: "Columbia! While the Sons of fame / Thy freedom through the world proclaim / And hell-born tyrants dread the name / That wills all nations free; Remote, on Barb'ry's pirate coast, By foes enslav'd, a miscreant host, / No more the rights of man we boast; / Adieu, blest Liberty!" (quoted in Gilje 2004, 153).

14. As Rojas reports, Benjamin Franklin, in 1773, had connected the economic success of American piracies in the Caribbean and along the Atlantic coast, fearing these would lead to "a new Barbary rising in America" and that in the future, "American corsairs" rather than Ottoman ones would plague the world (quoted in Rojas 2003, 165). On the Barbary crisis and the discourse of captivity in the U.S.-American public sphere, see Peskin (2009).

15. See especially his extensive introduction to White Slaves, African Masters: An Anthology of American Barbary Captivity Narratives $(1999,29)$ and the essay "The Barbary Captivity Narrative in American Culture" (2004).

16. Berman summarizes that Barbary pirates were mostly soldiers of fortune rather than citizens of North African states, the majority (Baepler draws on sources saying two thirds, 1995, 101) European renegados, many of them former captives who had converted to Islam and hence operate their raiding missions freely from North African ports (Berman 2007, 23 n.2). Captivity and cultural exchange in American literature are the main subjects of Michelle Burnham's important study Captivity and Sentiment (2000), but she does not discuss Barbary captivity.

17. On impressment in the literature of the Revolutionary period, see Gilje (2004, 157-59).

18. For biographical accounts of Philip's life, see the various publications by Selwyn Cudjoe as well as one of C. L. R. James's earliest writings, a biographical essay on Philip published in The Beacon in 1931. In this essay, James points to "some future occasion" ([1931] 1978, 255) on which he would discuss Philip's novel, but the occasion apparently never arrived (Nielsen 1997, 4).

19. Jeffrey Bolster briefly examines the historical relation between African Americans and piracy in the first chapter of Black Jacks: African American Seamen in the Age of Sail (1997). For a critique of Bolster through an economic reading of black mariners' narratives such as Equiano's, see Kazanjian (2003, 35-84).

20. For a detailed account of the book's historical context as it relates to slavery, see Cain (1997, xxiv-xxxiv). On the political crisis following the Fugitive Slave Act, see Holt (1978) and Varon (2008, ch. 6). 
21. According to Cudjoe, Philip had encountered the motif of revenge in Euripides's play Hecuba, which is cited in the novel's epigram (2003, 124; also Cain 1997, xxxviii). Cynthia James places Philip's novel in the context of the "maroon paradigm," referring to the runaway slaves of African origin in the Americas $(2002,50-53)$. This critical paradigm, according to Caribbean cultural theorists such as Kamau Brathwaite, revolves around tropes of abandonment, flight, and resistance, as well as around questions of ancestry and filiation. James emphasizes Appadocca's restlessness, homelessness, and multiculturalism.

22. As Gesa Mackenthun argues, the fact that his mother is of partSpanish descent means that Appadocca assumes two subaltern (or at least marginal) positions at once $(2004,110)$. The trace of his Spanish heritage is visible in the protagonist's name, probably inherited from his mother, which combines Jesus's first name and that of the legendary Spanish Vice Admiral Don Sebastian Ruiz de Apodaca, who had surrendered Trinidad to the British in 1797 (see Cudjoe in Philip [1854] 1997, 3).

23. Another significant appropriation concerns the protagonist's use of the "cultural property of the white, Western world, making it equally his as a resource for the composition of literature that both will and will not be part of the classic tradition," as Cain (1997, xxxix) comments on the text's frequent use of quotes from the classical canon of Western literature.

24. On the trope of Ethiopian splendor and Egyptian civilization in nineteenth-century culture, see Mackenthun $(2004,144)$ as well as Cudjoe $(2003,126$ n. $16 \& 17$ and 129-30).

25. There are in fact two romantic subplots, one concerning the former captive Agnes, who eventually is united with Appadocca's Spanish mate Lorenzo (who turns out to be the respectable St. James Carmonte); the second romantic liaison concerns Feliciana, daughter of a Venezuelan Ilanero, who falls in love with Appadocca when he is rescued from the coast and tries to make him renounce his plan of revenge and piracy altogether.

26. The yearning for a more stable home surfaces near the end of the book, when, in a letter to his friend Charles shortly before Appadocca's death, the protagonist reports that he plans to "lead the men who have followed me so bravely ... to some remote spot on the fertile and vast continent that lies on our right, and build them a city in which they may live happily, quietly, and far removed from the world, whose sympathy they cannot hope, and care not, to possess" (Philip [1854] 1997, 236); also before his death, he arranges that "half [of his treasure] shall be devoted to a college for abandoned children" (243).

27. The title is invariably cited by critics as a short story, using quotation marks around it, or as a short novel, italicizing it. I am using the short 
story citation because my reading emphasizes the text's formal experiments and significant open-end characteristic of the short story (also Levine 1989, 224).

28. For a reading of "Benito Cereno" as a detective story, see Haegert (1993, 27-30).

29. See also Burkholder's dated but still helpful summary research review (1992).

30. I am following Sale's diagnosis of a four-part narrative structure (1997, 153) here as it seems more precise than traditional views assuming only three (sometimes even two) parts.

31. Levine's interpretation of the slogan, in my view, hits the mark best: under its proper figurehead of Columbus, it "resonates not only as a grim prophecy on republican America's inability to transcend imperial Spain's historical crimes, but also as a grimly ironic reminder of Babo's willingness to assume a Spanish-like captaincy" $(1989,221)$.

32. Mackenthun reads Babo himself as a hybrid reincarnation of L'Ouverture, "a composite figure of the historical characters Singue, leader of the Amistad revolt, and Toussaint L'Ouverture ... mixed with traces of African trickster figures" $(2004,125)$.

33. Carolyn Karcher explains how the trope of piracy connects "Benito Cereno" and the Amistad case: "Charges of piracy were central to the trial. The press had repeatedly described the Amistad as a pirate ship when it was sighted ..., but the Africans' defense team ... successfully argued that it was not piracy for persons to rise up against those who illegally held them captive" (1990, 2465; also Thomas 1987, 108).

34. The play was based "on the late extraordinary 'Piracy! Mutiny! \& Murder!' aboard the Amistad and the sensational reports of 'black pirates' that had appeared in the press before their capture" and "demonstrated how quickly the news of the rebellion spread, and with what cultural resonance." Its title was derived from a New York Sun article about the Amistad rebellion "which in turn had drawn on the recent descriptions of a pirate ship ... marauding in the Gulf of Mexico" (Rediker 2012, 114).

35. On the parallel construction of the U.S. South and the Catholic Spanish Empire in "Benito Cereno," see Levine $(1989,202)$.

36. Melville anticipates his "revolutionary mutiny against the ship's hierarchical order" in Moby-Dick, completing "the disintegration of the sinking ship to initiate Steelkilt's career as a roving pirate" (Levine 1989, 193).

37. According to Reichardt, the scene presents two levels of signification at once, depending on the observer: "Das Zeichen zeigt gleichsam for weiße bzw. schwarze Teilnehmer in unterschiedliche Richtungen. Die Semantik ist von der Pragmatik abhängig; man könnte deshalb ... von einem 'gespaltenen Signifikanten' sprechen" (2001, 136). 
38. See Reichardt $(2001,129)$, who diagnoses the narration with a personal perspectivation (following F. K. Stanzel's narratological model).

39. Levine $(1989,225-26)$ remarks in this context that the critique of western rationality and legal language in the novella teaches a lesson to be learned from the crisis of the 1850 s, i.e., that knowledge alone will not necessarily lead to a better understanding of white-black and imperial relations. On interpretations of "Benito Cereno" from a law-and-literature perspective, see also DeLombard (2009), Thomas (1987, 93-112), and Weiner (1992).

40. Haegert's term is useful for my reading, though I am hesitant to concur with his diagnosis that "the indeterminacy that characterizes Benito Cereno derives less from some inherently unstable property of language than from the author's own uneasiness in portraying an oppressed and voiceless other" $(1993,22)$. Since authority and authorship are deconstructed by the novella, as Haegert himself concludes (32), such an author-centered statement remains unconvincing-this is not to say, however, that the text does not suggest Melville's awareness of linguistic instability.

41. That Melville collapsed Babo and Muri, Babo's son, who, on the Tryal, played the part of Benito's body servant, serves to highlight in this context that he "was interested not in a slave-father's power of his son, but in a slave-son's power over his father-master" ([1855-1856] 2002, 215).

42. "nicht nur darin weiter als andere Texte des 19. Jahrhunderts ..., daß er die Homogenitätsbehauptung einer westlichen, hier spezifisch amerikanischen Geschichte und Zivilisation binnentextuell dekonstruiert und so zur Einsicht in die Vielheit der Erfahrungen und Deutungen einer durch die Kolonisierung Amerikas, den Dreieckshandel und die ... Entstehung eines 'atlantischen' kulturhybriden Raumes bestimmten Geschichte beiträgt, sondern ... auch implizit die konzeptuellen Kosten eines perspektivischen ... Denkens vorführt. Melvilles ... epistemologische Skepsis läßt sich nicht ohne seine zivilisations- und rassendifferenzkritische Analyse verstehen; seine politische Kritik läßt sich wiederum nicht ohne die epistemologische Reflexion erklären" (in the German original; my translation).

43. Franklin $(1992,237)$ reveals that the historical Delano was in fact a privateer and emphasizes that he was regarded as a pirate by his enemies.

44. On filibustering and U.S. expansion in the period's literature, see Breinig (2008).

45. Though he can only speak through the multivalent language of the body (Zagarell 1992, 136), Babo's final image in the last paragraph is that of "an almost disembodied brain" (Karcher 1980, 130): "The body was burned to ashes; but for many days, the head, that hive of subtlety, fixed on a pole in the Plaza, met, unabashed, the gaze of the whites" (102); critics largely agree that this is perhaps the tale's most significant critique of racism. 
46. On the conundrums of authority and authorship in "Benito Cereno," see Zagarell (1992, 136-41).

47. Karcher views "The Bell-Tower" as the more radical of the two tales, confronting the reader "directly with a slave society's naked contempt for human values" (1980, 147).

48. Mackenthun characterizes this as a "temporality of the uncanny," based on a Freudian understanding as "the frightening return of old and long familiar knowledges," and a Benjaminian view of history as "a present 'shot through' with glimpses of past events" $(2004,122)$ - a view opposed to Delano's call to forget the past.

49. See also Bowman: "many Confederates invoked the natural right of revolution against tyranny and despotism that they saw articulated in the Declaration of Independence. Most of their opponents ... interpreted the Declaration as a manifesto for republican liberty against despotic slavery, which constituted a decidedly anti-American institution embodying tyranny. And they saw the Constitution, properly interpreted, as having created a substantial degree of state's rights but not state sovereignty within a prosperous, powerful, and perpetual Union. This judgment led them to view secession as a form of unreasonable and insufferable treason against the authority of the finest constitutional republic and most successful democratic experiment in the annals of history" $(2010,18)$.

50. See e.g., the trial of William Smith, which debated the status of Secession and its legitimacy as intensely as the definition of piracy.

51. Cobb notes that "covers" refers only to those envelopes that were actually used and thus carried a stamp or postal mark $(1963 / 1965,236)$. Other scholars use the terms interchangeably, however.

52. Due to the lack of traditional literary production, Daniel Aaron famously called the War an "Unwritten War" in 1973. Fahs counters this by focusing on the plethora of popular literature, flourishing in the 1860s; articulating attitudes toward gender and race, this body of writing "helped to shape new modes of imagining individuals' relationships to the nation" (2001, 2), including new relations between blacks and whites.

53. Gallagher (2011) cites the lack of slavery and emancipation themes on patriotic covers as evidence in support of his main thesis that the Civil War was more a War for Union than for the abolition of slavery.

\section{Works Cited}

\section{Primary Sources}

Defoe, Daniel. (1720) 1969. Captain Singleton. Oxford: Oxford University Press. 
"Encouragement for Pirates." 1861. New York Times, May 11. http://www.nyt imes.com/1861/05/11/news/encouragement-for-pirates.html.

Exquemelin, Alexander Olivier. (1678/1969) 2000. The Buccaneers of America. Translated by Alexis Brown. Mineola: Dover.

Lincoln, Abraham. "Proclamation 81-Declaring a Blockade of Ports in Rebellious States. April 19, 1861." In American Presidency Project, edited by Gerhard Peters and John T. Woolley. Accessed December 3, 2013. http:// www.presidency.ucsb.edu/ws/?pid=70101.

Melville, Herman. (1855-1856) 2002. "Benito Cereno." In Melville's Short Novels, edited by Dan McCall, 34-102. New York: W. W. Norton.

Philip, Michel Maxwell. (1854) 1997. Emmanuel Appadocca; or, Blighted Life: A Tale of the Boucaneers. Edited by Selwyn R. Cudjoe. Amherst: University of Massachusetts Press.

"President of the Cotton Confederacy Stimulating Piracy." 1861. Liberator, April 26, 23-24.

Rowson, Susanna Haswell. (1794) 2000. Slaves in Algiers or, a Struggle for Freedom. Acton: Copley.

Tyler, Royall. (1797) 2002. The Algerine Captive, or, the Life and Adventures of Doctor Updike Underbill. New York: Modern Library.

\section{SECONDARY Sources}

Allison, Robert J. 1995. The Crescent Obscured: The United States and the Muslim World, 1776-1815. Chicago: University of Chicago Press.

Ambrosius, Lloyd, ed. 1990. A Crisis of Republicanism: American Politics During the Civil War Era. Lincoln: University of Nebraska Press.

Anderson, Benedict. (1983) 2006. Imagined Communities. London: Verso.

Armitage, David. 2007. The Declaration of Independence: A Global History. Cambridge: Harvard University Press.

Baepler, Paul. 1995. "The Barbary Captivity Narrative in Early America." Early American Literature 30 (2): 95-120.

- 1999. "Introduction." In White Slaves, African Masters: An Anthology of American Barbary Captivity Narratives, edited by Paul Baepler, 1-58. New York: Oxford University Press.

- 2004. "The Barbary Captivity Narrative in American Culture." Early American Literature 39 (2): 217-246.

Beebee, Thomas O. 2006. "Carl Schmitt's Myth of Benito Cereno." Seminar: A Journal of Germanic Studies 42 (2): 114-134.

Berman, Jacob Rama. 2007. "The Barbarous Voice of Democracy: American Captivity in Barbary and the Multicultural Specter." American Literature 79 (11): 1-27. 
Berry, Stephen. 2005. "The Lithographer's War: Union and Confederate Patriotic Covers." North \& South 8 (3): 12-18.

Bestor, Arthur. 1964. "The Civil War as a Constitutional Crisis." American Historical Review 69: 327-53.

Birkle, Carmen, and Nicole Waller, eds. 2009. "The Sea Is History": Exploring the Atlantic. Heidelberg: Winter.

Blum, Hester. 2003. "Pirated Tars, Piratical Texts: Barbary Captivity and American Sea Narratives.” Early American Studies 1 (2): 133-158.

Blum, Hester. 2006. “Atlantic Trade." In A Companion to Herman Melville, edited by Wyn Kelley, 113-128. Oxford: Blackwell.

Bolster, W. Jeffrey. 1997. Black Jacks: African American Seamen in the Age of Sail. Cambridge: Harvard University Press.

Bowman, Shearer Davis. 2010. At the Precipice: Americans North and South During the Secession Crisis. Chapel Hill: University of North Carolina Press.

Boyd, Julian P. 1999. The Declaration of Independence: The Evolution of the Text. Washington: Library of Congress.

Boyd, Steven R. 2010. Patriotic Envelopes of the Civil War: The Iconography of Union and Confederate Covers. Baton Rouge: Louisiana State University Press.

Breinig, Helmbrecht. 2008. "Invasive Methods: The Opening of Latin America in Nineteenth-Century U.S. Literature." Amerikastudien/American Studies 53 (1): 14-36.

Brezina, Jennifer Costello. 2005. "A Nation in Chains: Barbary Captives and American Identity." In Captivating Subjects: Writing Confinement, Citizenship, and Nationhood in the Nineteenth Century, edited by Jason Harlam and Julia M. Wright, 201-219. Toronto: University of Toronto Press.

Buell, Lawrence. 1992. "American Literary Emergence as a Postcolonial Phenomenon." American Literary History 4 (3): 411-442.

Burkholder, Robert E. 1992. "Introduction." In Critical Essays on Herman Melville's "Benito Cereno," edited by R. E. Burkholder, 1-16. New York: Hall. Burnham, Michelle. 2000. Captivity and Sentiment: Cultural Exchange in American Literature, 1682-1861. Hanover: University Press of New England.

Cain, William E. 1997. "Introduction: Emmanuel Appadocca in Its American Context." In Emmanuel Appadocca; or, Blighted Life: A Tale of the Boucaneers, edited by Selwyn R. Cudjoe, xv-lv. Amherst: University of Massachusetts Press.

Channing, Steven A. 1970. Crisis of Fear: Secession in South Carolina. New York: Simon \& Schuster.

Cobb, Josephine. 1963/1965. "Decorated Envelopes in the Civil War." Records of the Columbia Historical Society Washington, D.C. 63-65: 230-239. 
Cudjoe, Selwyn R. 2003. Beyond Boundaries: The Intellectual Tradition of Trinidad and Tobago in the Nineteenth Century. Amherst: University of Massachusetts Press.

_ 1997a. "Afterword: Emmanuel Appadocca, the First Anglo-Caribbean Novel." In Emmanuel Appadocca; or, Blighted Life: A Tale of the Boucaneers, edited by S. R. Cudjoe, 249-275. Amherst: University of Massachusetts Press. . 1997b. "Preface." In Emmanuel Appadocca; or, Blighted Life: A Tale of the Boucaneers, edited by S. R. Cudjoe, ix-xiv. Amherst: University of Massachusetts Press.

Davidson, Cathy N. 2004. Revolution and the Word: The Rise of the Novel in America. Exp. ed. New York: Oxford University Press.

De Grave, Kathleen. 1995. Swindler, Spy, Rebel: The Confidence Woman in Nineteenth-Century America. Columbia: University of Missouri Press.

DeLombard, Jeannine Marie. 2009. "Salvaging Legal Personhood: Melville's Benito Cereno." American Literature 81 (1): 35-64.

DiNunzio, Mario. 1972. "Secession Winter: Lyman Trumbull and the Crisis of Congress." Capitol Studies 1: 29-39.

Emery, Allan Moore. 1992. “'Benito Cereno' and Manifest Destiny.” In Critical Essays on Herman Melville's "Benito Cereno," edited by Robert E. Burkholder, 99-115. New York: Hall.

Fahs, Alice. 2001. The Imagined Civil War: Popular Literature of the North and South, 1861-1865. Chapel Hill: University of North Carolina Press.

Franklin, H. Bruce. 1992. "Past, Present, and Future Seemed One." In Critical Essays on Herman Melville's "Benito Cereno," edited by Robert E. Burkholder, 230-246. New York: Hall.

Gallagher, Gary W. 2011. The Union War. Cambridge: Harvard University Press.

Gilje, Paul A. 2004. Liberty on the Waterfront: American Maritime Culture in the Age of Revolution. Philadelphia: University of Pennsylvania Press.

Goldberg, Shari. 2009. "Benito Cereno's Mute Testimony: On the Politics of Reading Melville's Silences." Arizona Quarterly: A Journal of American Literature, Culture, and Theory 65 (2): 1-26.

Graebner, Norman L. 1977. "Thomas Corwin and the Sectional Crisis." Ohio History 86: 229-247.

Greene, Jody. 2008. "Hostis Humani Generis.” Critical Inquiry 34 (3): 683705.

Haegert, John. 1993. "Voicing Slavery Through Silence: Narrative Mutiny in Melville's 'Benito Cereno.'” Mosaic 26 (2): 21-38.

Hanna, Mark G. 2015. Pirate Nests and the Rise of the British Empire, 15701740. Chapel Hill: University of North Carolina Press.

Heide, Markus. 2008. “Herman Melville's 'Benito Cereno,' Inter-American Relations, and Literary Pan-Americanism." In The Americas in the Nineteenth Century: Inter-American Perspectives on U.S. Literature, edited by Markus 
Heide and Gabriele Pisarz-Ramírez. Special issue, Amerikastudien/American Studies 53 (1): 37-56.

Holt, Michael F. 1978. The Political Crisis of the 1850s. New York: Wiley.

James, C. L. R. (1931) 1978. "Michel Maxwell Philip: 1829-1888." The Beacon 1 (6). Reprinted in From Trinidad: An Anthology of Early West Indian Writing, edited by Reinhard W. Sander, 253-269. London: Hodder and Stoughton.

- 1953. Mariners, Renegades and Castaways: The Story of Herman Melville and the World We Live in. New York: C.L.R. James.

James, Cynthia. 2002. The Maroon Narrative: Caribbean Literature in English Across Boundaries, Ethnicities, and Centuries. Portsmouth: Heinemann.

Jefferson, Thomas. 1776. "Declaration of Independence." Rough Draft. http:// www.ushistory.org/declaration/document/rough.htm.

Johannsen, Robert W. 1963. "The Douglass Democracy and the Crisis of Disunion." Civil War History 9: 229-247.

Kamuf, Peggy. 1997. The Division of Literature or the University in Deconstruction. Chicago: University of Chicago Press.

Karcher, Carolyn L. 1980. Shadow over the Promised Land: Slavery, Race, and Violence in Melville's America. Baton Rouge: Louisiana State University Press.

- 1990. "Notes to 'Benito Cereno.'” In The Heath Anthology of American Literature 1, edited by Paul Lauter et al., 2464-2522. Lexington: Heath.

Kavanagh, James. 1986. "That Hive of Subtlety: 'Benito Cereno' and the Liberal Hero." In Ideology and Classic American Literature, edited by Sacvan Bercovitch and Myra Jehlen, 352-383. New York: Cambridge University Press.

Kazanjian, David. 2003. National Culture and the Colonizing Trick: Imperial Citizenship in Early America. Minneapolis: University of Minnesota Press.

Klein, Bernhard, and Gesa Mackenthun, eds. 2004. Sea Changes: Historicizing the Ocean. New York: Routledge.

Knoles, George Harmon, ed. 1965. The Crisis of the Union, 1860-61. Baton Rouge: Louisiana State University Press.

Lambert, Frank. 2005. The Barbary Wars: American Independence in the Atlantic World. New York: Hill and Wang.

Lane, Kris. 2007. "The Life and Times of William Dampier: An Introduction." In William Dampier: A New Voyage Round the World. Warwick: 1500 Books.

Leiner, Frederick C. 2006. The End of Barbary Terror: America's 1815 War Against the Pirates of North Africa. Oxford: Oxford University Press.

Lennox, Sarah. 2017. “'Her English Ensign Tied Upside Down': Carnival as a Means of Anticolonial Resistance in Emmanuel Appadocca." The Journal of Commonwealth Literature 1: 1-16.

Levine, Robert S. 1989. Conspiracy and Romance: Studies in Brockden Brown, Cooper, Hawthorne, and Melville. Cambridge: Cambridge University Press. 
Lewis, Gordon K. (1983) 2004. Main Currents in Caribbean Thought: The Historical Evolution of Caribbean Society in Its Ideological Aspects, 1492-1900. Lincoln: University of Nebraska Press.

Lewis, James R. 1990. "Savages of the Seas: Barbary Captivity Tales and Images of Muslims in the Early Republic." Journal of American Culture 13 (2): 75-84.

Mackenthun, Gesa. 2004. Fictions of the Black Atlantic in American Foundational Literature. London: Routledge.

- 2006. "'Between Worlds': Edward Said and the Rediscovery of Empire in American Studies." In America and the Orient, edited by Heike Schaefer, 1-20. Heidelberg: Winter.

Margulis, Jennifer, and Karen Poremski. 2000. "Introduction." In Slaves in Algiers, or, a Struggle for Freedom, by Susanne Rowson, vii-xxix. Acton: Copley.

Matthiessen, F. O. 1941. The American Renaissance. London: Oxford University Press.

McClintock, Russell. 2008. Lincoln and the Decision for War: The Northern Response to Secession. Chapel Hill: University of North Carolina Press.

Montgomery, Benilde. 1994. "White Captives, African Slaves: A Drama of Abolition." Eighteenth-Century Studies 27 (4): 615-630.

Morrison, Toni. 1992. Playing in the Dark: Whiteness and the Literary Imagination. Cambridge: Harvard University Press.

Nickels, Cameron C. 2010. Civil War Humor. Jackson: University of Mississippi Press.

Nielsen, Aldon Lynn. 1997. C.L.R. James: A Critical Introduction. Jackson: University Press of Mississippi.

Nnolim, Charles E. 1974. Melville's "Benito Cereno": A Study in Meaning of Name Symbolism. New York: New Voices.

Paludan, Phillip S. 1972. "The American Civil War Considered as a Crisis in Law and Order." American Historical Review 77: 1013-1034.

Pedersen, Carl. 1994. "Sea Change: The Middle Passage and the Transatlantic Imagination." In The Black Columbiad: Defining Moments in African American Literature and Culture, edited by Werner Sollors and Maria Diedrich, 42-51. Cambridge: Harvard University Press.

Peskin, Lawrence A. 2009. Captives and Countrymen: Barbary Slavery and the American Public, 1785-1816. Baltimore: Johns Hopkins University Press.

Procter, James. 2007. "Diaspora." In The Routledge Companion to Postcolonial Studies, edited by John McLeod, 151-157. London: Routledge.

Rediker, Marcus. 2012. The Amistad Rebellion: An Atlantic Odyssey of Slavery and Freedom. New York: Penguin.

Reichardt, Ulfried. 2001. Alterität und Geschichte: Funktionen der Sklavereidarstellung im amerikanischen Roman. Heidelberg: Winter. 
Robinson, Ben. 2014. "Disassembling the 'San Dominick': Sovereignty, the Slave Ship, and Partisanship in Herman Melville's Benito Cereno." In Producing Places, edited by Lorenz Engell and Bernhard Siegert. Special issue, Zeitschrift for Medien- und Kulturforschung 5 (1): 135-150.

Rogin, Michael Paul. (1979) 1985. Subversive Genealogy: The Politics and Art of Herman Melville. Berkeley: University of California Press.

Rojas, Martha Elena. 2003. “'Insults Unpunished': Barbary Captives, American Slaves, and the Negotiation of Liberty." Early American Studies 1 (2): 159186.

Rosenberg, Norman L. 1971. "Personal Liberty Laws and the Sectional Crisis: 1850-1861." Civil War History 17: 25-44.

Roundy, Nancy. 1978. "Present Shadows: Epistemology in Melville's 'Benito Cereno."” Arizona Quarterly 34: 344-350.

Sale, Maggie Montesinos. 1997. The Slumbering Volcano: American Slaveship Revolts and the Production of Rebellious Masculinity. Durham: Duke University Press.

Schmitt, Carl. (1937) 2005. "Der Begriff der Piraterie [1937]." In Frieden oder Pazifismus? Arbeiten zum Völkerrecht und zur internationalen Politik, 19241978, edited by Günter Maschke, 509-511. Berlin: Duncker \& Humblot.

-. (1942) 2008. Land und Meer: Eine weltgeschichtliche Betrachtung. Stuttgart: Klett-Cotta.

Greven.

Schnackertz, Hermann Josef. 1993. "Wahrnehmungsperspektiven als Medium kultureller Exploration in Herman Melvilles Typee und Benito Cereno." In Vergessen. Entdecken. Erhellen: Literaturwissenschaftliche Aufsätze, edited by Jörg Drews, 161-182. Bielefeld: Aisthesis.

Schueller, Malini Johar. 1998. U.S. Orientalisms: Race, Nation, and Gender in Literature, 1790-1890. Ann Arbor: University of Michigan Press.

Scudder, Harold. 1928. "Melville's Benito Cereno and Captain Delano's Voyages." PMLA 43: 502-532.

Smith, Faith. 1999. "Beautiful Indians, Troublesome Negroes, and Nice White Men: Caribbean Romances and the Invention of Trinidad." In Caribbean Romances: The Politics of Regional Representation, edited by Belinda J. Edmondson, 163-182. Charlottesville: University Press of Virginia.

Stampp, Kenneth M. 1945. "Lincoln and the Strategy of Defense in the Crisis of 1861." Journal of Southern History 9: 297-323.

Stephens, John Richard, ed. 1996. Captured by Pirates: Firsthand Accounts of Murder and Maybem on the High Seas. Cambria Pines: Fern Canyon Press.

Stratton, Billy J. 2013. Buried in Shades of Night: Contested Voices, Indian Captivity, and the Legacy of King Philip's War. Tucson: University of Arizona Press. 
Stuckey, Sterling. 2009. African Culture and Melville's Art: The Creative Process in Benito Cereno and Moby-Dick. Oxford: Oxford University Press.

Stuckey, Sterling, and Joshua Leslie. 1988. “Aftermath: Captain Delano's Claim Against Benito Cereno." Modern Philology 85: 265-287.

Sundquist, Eric J. 1986. "Benito Cereno and New World Slavery." In Reconstructing American Literary History, edited by Sacvan Bercovitch, 93-122. Cambridge: Harvard University Press.

Sutton, Angela. 2009. "Atlantic Orientalism: How Language in Jefferson's America Defeated the Barbary Pirates." In Pirates and Piracy, edited by Andrew Opitz. Special issue, Darkmatter 5. http://www.darkmatter101.org/ site/2009/12/20/atlantic-orientalism.

Tawil, Ezra. 2006. The Making of Racial Sentiment: Slavery and the Birth of the Frontier Romance. Cambridge: Cambridge University Press.

Thomas, Brook. 1987. Cross-Examinations of Law and Literature: Cooper, Hawthorne, Stowe, and Melville. New York: Cambridge University Press.

Tinniswood, Adrian. 2010. Pirates of Barbary: Corsairs, Conquests and Captivity in the Seventeenth-Century Mediterranean. New York: Riverhead Books/Penguin.

Varon, Elizabeth R. 2008. Disunion! The Coming of the American Civil War, 1789-859. Chapel Hill: University of North Carolina Press.

Vitkus, Daniel. 2001. Piracy, Slavery, and Redemption: Barbary Captivity Narratives from Early Modern England. New York: Columbia University Press.

Weiner, Susan. 1992. Law in Art: Melville's Major Fiction and NineteenthCentury American Law. New York: Peter Lang.

Weitz, Mark. 2005. The Confederacy on Trial: The Piracy and Sequestration Cases of 1861. Lawrence: University Press of Kansas.

Zagarell, Sandra A. 1992. “Reenvisioning America: Melville's 'Benito Cereno'.” In Critical Essays on Herman Melville's "Benito Cereno," edited by Robert E. Burkholder, 127-145. New York: Hall. 
Open Access This chapter is licensed under the terms of the Creative Commons Attribution 4.0 International License (http://creativecommons.org/licenses/ by/4.0/), which permits use, sharing, adaptation, distribution and reproduction in any medium or format, as long as you give appropriate credit to the original author(s) and the source, provide a link to the Creative Commons license and indicate if changes were made.

The images or other third party material in this chapter are included in the chapter's Creative Commons license, unless indicated otherwise in a credit line to the material. If material is not included in the chapter's Creative Commons license and your intended use is not permitted by statutory regulation or exceeds the permitted use, you will need to obtain permission directly from the copyright holder.

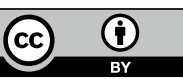

